\title{
Health Concerns of Various Nanoparticles: A Review of Their in Vitro and in Vivo Toxicity
}

\author{
Marziyeh Ajdary ${ }^{1}$ (D), Mohammad Amin Moosavi ${ }^{2}$, Marveh Rahmati ${ }^{3}$, Mojtaba Falahati ${ }^{4}$, \\ Mohammad Mahboubi ${ }^{5}$, Ali Mandegary ${ }^{6,7}$ (1) , Saranaz Jangjoo ${ }^{8, *}$, Reza Mohammadinejad ${ }^{6, *}$ \\ and Rajender S. Varma ${ }^{9, *}$ (iD) \\ 1 Cellular and Molecular Research Center, Iran University of Medical Sciences, \\ Tehran P.O. Box 1449614525, Iran; Maa.biology92@gmail.com \\ 2 Department of Molecular Medicine, National Institute of Genetic Engineering and Biotechnology, \\ Tehran P.O Box 14965/161, Iran; a-moosavi@nigeb.ac.ir \\ 3 Cancer Biology Research Center, Cancer Institute of Iran, Tehran University of Medical Sciences, \\ Tehran P.O. Box 13145-158, Iran; m_rahmati@sina.tums.ac.ir \\ 4 Department of Nanotechnology, Faculty of Advance Science and Technology, Pharmaceutical Sciences \\ Branches, Islamic Azad University of Tehran, Tehran P.O. Box 1916893813, Iran; Falahati@ibb.ut.ac.ir \\ 5 Department of Midwifery and Reproductive Health, Faculty of Nursing and Midwifery, Abadan School of \\ Medical Sciences, Abadan P.O. Box 517, Iran; Mm59m@yahoo.com \\ 6 Pharmaceutics Research Center, Institute of Neuropharmacology, Kerman University of Medical Sciences, \\ Kerman P.O. Box 1355576169, Iran \\ 7 Neuroscience Research Center, Institute of Neuropharmacology, and Department of Pharmacology \& \\ Toxicology, School of Pharmacy, Kerman University of Medical Sciences, Kerman P.O. Box 7616911319, Iran; \\ alimandegary@yahoo.com \\ 8 School of Medicine, International Branch, Shiraz University of Medical Sciences, Shiraz 7134845794, Iran \\ 9 Regional Centre of Advanced Technologies and Materials, Faculty of Science, Palacky University in \\ Olomouc, Šlechtitel ů 27, 78371 Olomouc, Czech Republic \\ * Correspondence: saranazjangjoo@gmail.com (S.J.); reza.mn2008@gmail.com (R.M.); \\ varma.rajender@epa.gov (R.S.V.); Tel: +98-93-7839-2628 (S.J.); +98-91-3247-9160 (R.M.); +1-513-487-2701 \\ (R.S.V.); Fax: +98-71-3235-9317 (S.J.); +98-34-3132-5003 (R.M.); +1-513-569-7677 (R.S.V.)
}

Received: 1 August 2018; Accepted: 15 August 2018; Published: 21 August 2018

\begin{abstract}
Nanoparticles (NPs) are currently used in diagnosis and treatment of many human diseases, including autoimmune diseases and cancer. However, cytotoxic effects of NPs on normal cells and living organs is a severe limiting factor that hinders their use in clinic. In addition, diversity of NPs and their physico-chemical properties, including particle size, shape, surface area, dispersity and protein corona effects are considered as key factors that have a crucial impact on their safe or toxicological behaviors. Current studies on toxic effects of NPs are aimed to identify the targets and mechanisms of their side effects, with a focus on elucidating the patterns of NP transport, accumulation, degradation, and elimination, in both in vitro and in vitro models. NPs can enter the body through inhalation, skin and digestive routes. Consequently, there is a need for reliable information about effects of NPs on various organs in order to reveal their efficacy and impact on health. This review covers the existing knowledge base on the subject that hopefully prepares us better to address these challenges.
\end{abstract}

Keywords: nanoparticles; toxicological effects; organ-specific effects

\section{Introduction}

Nanoparticles (NPs) have become widely used in electronics, agriculture, textile production, medicine, and many other industries and sciences (Figure 1) The International Organization for 
Standardization define NPs as structures whose sizes in one, two, or three dimensions are within the range from 1 to $100 \mathrm{~nm}$ [1-5]. Apart from size, NPs may be classified in terms of their physical parameters, e.g., electrical charge; chemical characteristics, such as the composition of the NP core or shell; shape (tubes, films, rods, etc.); and origin: natural NPs (NPs contained in volcanic dust, viral particles, etc.) and artificial NPs, which are the focus of this review [6]. NP toxicity for living organisms, however, is the main factor limiting their use in treatment and diagnosis of diseases. At present, researchers often face the problem and side effects related to their toxicity. In this respect, the choice of an adequate experimental model for estimating toxicity in vitro (cell lines) and in vivo (experimental animals) ones is of paramount importance. NPs can enter into the body through inhalation, skin, and digestion, depending on their physicochemical characteristics and mode of their production [7]. The interactive contact with the body, depending on the type of compounds in NPs, can be respiratory, digestive, or through skin or blood [8]. Some of NPs, such as $\mathrm{ZnO}$ and $\mathrm{TiO}_{2}$, have the ability to block UV rays and are extensively used in various health products on the market, which raises concerns about their risks to health, safety and the environment as they are dispersed in the environment. According to primary studies, NPs can enter human body in different ways and they can access vital organs in the body through the blood flow and induce damage to tissues and cells $[1,7,8]$. Although the mechanism of NPs in this regard is not truly established, researchers have associated the toxicity of NPs to parameters such as particle shape, size, dispersity, surface charge and protein corona effects. Several studies have indicated that NPs activate oxidative stress and expression of genes involved in inflammation [9-11]. NPs can enter the human body through respiration, ingestion, and injection and consequently accumulate into different tissues and organs [11-14]. NPs can even reach the brain by breaking the strong connection between cells and passing through the blood-brain barrier (BBB); they attach to the cells containing CXCR6 chemokine receptor and overcome tight injunction in the BBB [15]. The NPs' passage through the membrane, their performance, and their cell metabolism are still being studied and discussed. Thus, herein, we attempt to explain a part of the NPs performance that hopefully can answer whether NPs have destructive and toxic effects on organs, or are they safe enough [6]. Development of safe, biocompatible NPs that can be used for the diagnosis and treatment of human diseases can only be based on a complete understanding of the interactions between all of the factors and mechanisms underlying NP toxicity (Figure 1).

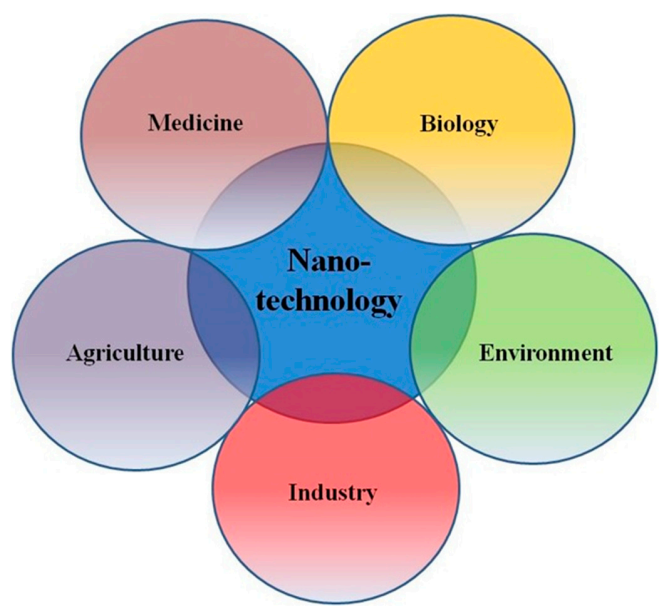

Figure 1. Nanotechnology transformative innovations in medicine, agriculture, industry, environment, and basic biological sciences.

Although the safety of many of their chemical components in medicine has been examined, the toxic effect of NPs may be caused by their unique physical and chemical properties, which define the specific mechanisms of interaction with living organs, tissues, and cells. In general, this rationalizes the importance of studying the causes and mechanisms of the potential toxic effect of NPs. 


\section{Medical Applications of Nanoparticles}

In medicine, NPs can be used for diagnostic or therapeutic purposes. In diagnosis, they can serve as fluorescent labels for detection of biomolecules and pathogens and as contrast agents in magnetic resonance and other studies. In addition, NPs can be used for targeted delivery of drugs, including protein and polynucleotide substances; in photodynamic therapy and thermal destruction of tumors, and in prosthetic repair [16]. Some types of NPs have been used extensively in drug delivery, diagnosis of diseases and the provision of biologic sensors; several nanometals have been produced and evaluated, but gold and silver are the most widely used. These particles can be prepared in different sizes and shapes, with a small particle size distribution. One of the unique features of these particles is their optical behavior change by changing the particle size, meaning that NPs of different sizes exhibit different colors at visible wavelengths. This feature can be used for diagnosis of the disease and eventual drug delivery to facilitate both these processes. The surface variation of these particles is easy to manipulate as various ligands such as sugars, peptides, proteins, and DNA can bind to these particles [17].

Iron oxide superparamagnetic NPs are an important and widely used category of inorganic materials used in drug delivery that can be prepared by chemical procedures such as co-precipitation method or via biological means with the help of bacteria. Easy modification of the particles' surface, as well as direct bonding of the ligand to them, are salient features of these compounds. In addition, having superparamagnetic property enables the use of these compounds in targeted drug delivery via the magnetic field. Magnetic NPs loaded with a drug can be guided to a specific place in the body by the application of an external magnetic field, thereby bringing the drug to a specific place. For example, $\mathrm{Fe}_{3} \mathrm{O}_{4}$ (magnetite), $\gamma-\mathrm{Fe}_{2} \mathrm{O}_{3}$ (maghemite, ferrimagnetic) and superparamagnetic iron oxide NPs (SPIONs) are the major NPs used in drug delivery. These particles are typically coated with polymers such as dextran or chitosan to enhance their biocompatibility [18]. Two classes of compounds that have recently been highly emphasized in the drug delivery are carbon nanotubes and fullerenes (also known as Buckyballs); their size, shape and surface properties have empowered their use in drug delivery. Single-wall carbon nanotubes and C60 fullerenes have a diameter of about 1 nanometer, which is half the diameter of a DNA helix. Because of their small size, these particles can easily pass through the membranes and biological barriers and penetrate into the cell. These structures allow for surface engineering with their high surface to volume ratio. The surface of these particles can be coated with various compounds to enhance solubility and biocompatibility, as well as the delivery of different materials including biological molecules such as proteins, DNA and drugs. Pharmaceutical compounds are often loaded onto or inside these structures. Targeting and simultaneous transfer of two or more compounds are additional interesting features of importance in drug delivery by these particles [17].

The term liposome was coined in 1961 by Alec D. Bangham. These double-layer vesicles consist of a liquid part enclosed in a double layer lipid membrane, which is often a natural or synthetic phospholipid. Amphiphilic nature, biocompatibility and the ease of surface changes are among the factors that initiated the use of these structures as an option for drug delivery $[17,19]$. Another example of lipid nanostructures is solid lipid NPs (SLNs) that form a solid lipid matrix consisting of triglycerides, lipids, fatty acids, steroids and waxes, and have a size less than $1 \mu \mathrm{m}$. In order to increase the stability of these particles, surfactant compounds are often deployed in their formulation. These NPs can be used to load and carry drugs with very low solubility in an aqueous medium, release them in a specific time frame, and transfer them to the desired site via, for instance, oral methods or injection [20]. Another very commonly used materials, in the form of NPs for drug delivery, are polymers, natural or synthetic, which need to be biocompatible, non-toxic and free from leachable impurities besides comprising an appropriate physical structure and a desired half-life. Polymer NPs are often selected from biodegradable types, the main advantage being their high stability and their scale-up production in large quantities. These involve a large number of compounds that form vesicular systems (nanocapsules) and matrix systems (nanospheres); the drug is kept inside a polymeric 
cavity in nanocapsules, while it is dispersed in a polymer matrix in nanospheres [17,20]. Polymer micelles are self-assemblies of macromolecules that consist of block copolymers with non-covalent bonds; block copolymer micelles have a core-shell structure. Specific properties of the micelles, such as critical micellization concentration (CMC), aggregation number, size and shape of their final structure depend on the structure and length of the polymer chains in the copolymer block. Polymer micelles usually have a low CMC, which affects their ability to increase the solubility of loaded drugs and the resistance of micelles $[20,21]$ which can be effective in reducing the speed of drug release. These structures also have more mechanical and biological stability compared to liposomes because the interaction of vesicles and macrophages is less common in these structures, resulting in more protection for the drug. Despite all these advantages, there is still no formulation for this structure class in the pharmaceutical market. Hydrogel NPs are three-dimensional polymer structures used to encapsulate and transfer drugs. These structures swell in water or in the bioenvironment and carry a large amount of fluids inside. There are also stimulus-responsive hydrogels which release the drug under specific environmental changes, such as temperature and $\mathrm{pH}$ changes. These systems have been used to transfer DNA and proteins, heal wounds, make biosensors, and engineer tissues [17].

\section{Mechanisms of Nanoparticle Toxicity: NP-Cell Interactions}

Surface properties of NPs, namely hydrophobicity and hydrophilicity, affect many of the biological environmental responses of these structures, such as interaction with plasma proteins, cellular uptake and phagocytosis, stimulation of the immune system and particle removal. The surface properties of nanoparticles result in different cellular responses such as adhesion, growth and differentiation. The oxidative stress is induced by NPs through physicochemical interaction in the cell membrane as they generate ions which cause toxicity in the cell membrane surface and that can be exploited to eliminate cancer cell [22]. The higher the diameter of the NPs, the more their interaction with the surface of the cell membrane and the higher the level of cellular toxicity. The cell membrane is complex and dynamic comprising proteins and extracellular polymeric materials. As shown in Figure 2, the penetration of NPs occurs through intrusion at the diffusion, endocytosis and membrane proteins such as phospholipid layer. NPs are subsequently localized in endosomes and nucleus, degraded in lysosomes or recycled back to the plasma membrane although the mechanism may still be unclear. The toxicity of Au NPs with a diameter under $100 \mathrm{~nm}$ have been explored. In the range of 3, 5, 50 and $100 \mathrm{~nm}$, the toxicity was observed for the biggest and smallest sizes which included apoptosis, oxidative stress, organelles and DNA destruction, and mutagenesis [23]. NPs enter cell through endocytosis and their toxicity is predominantly through an increase of reactive oxygen species (ROS) levels in the cell (Figure 2).

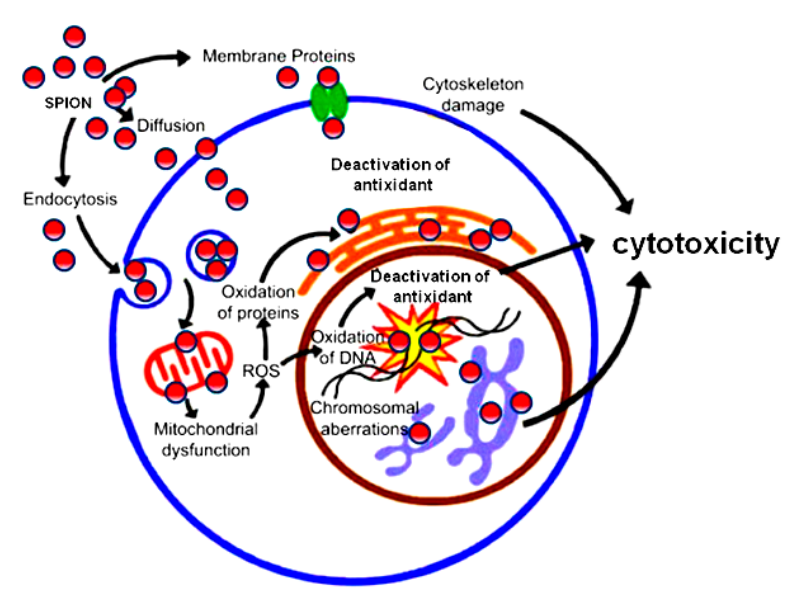

Figure 2. The main routes of nanoparticles (NP) entry into the cells and their subsequent intracellular mechanism(s) [24]. 
NPs can also increase inflammatory factors such as TNF- $\alpha, 11-8,11-6,11-1$, and ultimately cause mitochondrial damage (Figure 3) [24-26]. The interaction of NPs with the cell surface ligand and membrane receptors is the main connection route for drug delivery and this is implemented through endocytosis. Recently, with the aim of reducing the toxicity of NPs in drug delivery, amphipathic Au NPs have been used. Being hydrophobic, they are protected against microbial attacks, swelling or changes in pores due to $\mathrm{pH}$ changes as these NPs pass through membrane without damage; a behavior reminiscent of the cyclic citrullinated peptide (CCP) for Rheumatoid arthritis therapy. $\alpha$-helix protein has a hydrophilic part and a hydrophobic part and CCP bonds with cationic group, enters the cell and connects with the negative charge remained from the membrane [27]. The factors that are important in the connection of NPs to the cell surface protein are surface charge and hydrophobicity of the particles and the particles reaction with the protein tail or phospholipid head; the cationic level being stronger than the anionic level in this process. The interaction of NPs with water molecules, their hydrophobic property, is in fact a factor for drug delivery properties for medications whose transfer is otherwise difficult. Coating NPs with ligands impacts the size, ligand density, receptor emission, and free energy changes. The rod and cylindrical shapes of NPs, compared with the spherical shape, need more time for wrapping and this is due to the thermodynamic force for engulfment [28]. The interaction of NPs with macromolecules such as protein has been explored and such interface can result in structural changes of proteins [29]; proteins have multiple 3D structures and some structures change after attachment of NPs due to diversity of amino acids and the protein performance. NPs such as C60 fullerenes and SWCNTs with attachments, for destruction of the activity of enzymes such as human immunodeficiency virus type 1 protease (HIV-1p) and S-DNA-glutathione, are used for therapeutic purposes [30]. But these features may also underline their toxicity in living organ, the key mechanism responsible for the cytotoxic effects of NPs being oxidative stress that results in an intracellular disharmony and consequently the increase of ROS (Figure 2). DNA strand damage is via base changes namely hydroxy deoxyguanosine formation and, when DNA is not repaired, the cell cross-linking results in the occurrence and progression of cancer. Oxidative stress subsequently activates various signaling pathways that may lead to cell death [31].

Briefly, the most common mechanisms of NP cytotoxicity entail the following (Figures 2 and 3):

1. NPs may cause oxidation via increase of reactive oxygen species (ROS)

2. NPs may damage cell membranes by perforating them

3. NPs damage components of the cytoskeleton, disturbing intracellular transport and cell division

4. NPs disturb transcription and damage DNA, thus accelerating mutagenesis

5. NPs damage mitochondria and disturb their metabolism, which leads to cell energy imbalance

6. NPs interfere with the formation of lysosomes, thereby hampering autophagy and degradation of macromolecules and triggering the apoptosis

7. NPs cause structural changes in membrane proteins and disturb the transport of substances into and out of cells, including intercellular transport

8. NPs activate the synthesis of inflammatory mediators by disturbing the normal mechanisms of cell metabolism, as well as tissue and organ metabolism (Figure 3).

The penetration of NPs can occur through diffusion, endocytosis and membrane receptor proteins. NPs are then localized in late endosomes, mitochondria, endoplasmic reticulum (ER) or nucleus, then induce signaling pathways that are mostly depended on ROS. Mitochondrial ROS can lead to accumulation of more levels of ROS and resultant oxidative stress may disrupt protein folding process, causing ER stress and induce DNA damage, leading to activation of cell death pathways [32].

Although some NPs, such as Ag NPs, are used as an antimicrobial agent because of this mechanism, inappropriate use of these NPs can damage other cells instead of microbes. For example, Ag NPs can be used to disinfect wounds and prevent the growth of bacteria in that area. They can prevent bacterial growth and replication through the above mechanisms and heal the wound. 
But, it should be noted that the same NPs can also affect the cells of human body around the injury site and cause cell death.

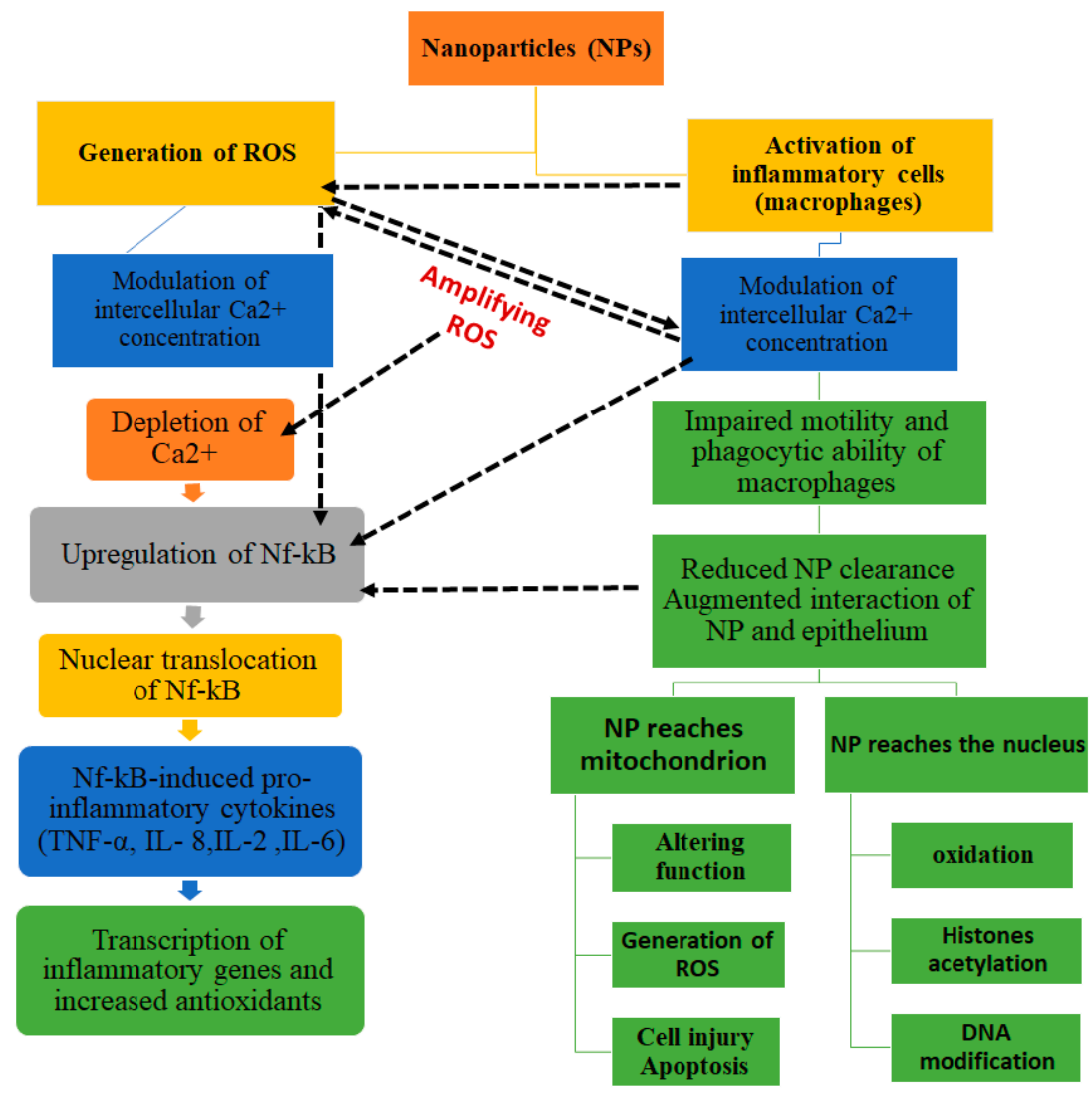

Figure 3. The most common mechanisms underlying NP cytotoxicity.

\subsection{The Effect of NP on the Protein Conformational Changes}

A number of techniques such as nuclear magnetic resonance (NMR) spectroscopy [33], X-ray crystallography [34], circular dichroism spectroscopy [35], isothermal calorimetry [36], differential scanning calorimetry [37], fluorescence spectroscopy [38], and UV-visible spectroscopy [39] have been widely used for analyzing the protein-NP interactions. The NP-induced conformational changes and subsequent corona formation depends on several factors such as, protein type, NP type, size of NP, shape of $\mathrm{NP}, \mathrm{pH}$ and the temperature.

Subtle changes in the structure of NPs affect their surface properties and subsequent interaction with proteins. The interaction of the single wall carbon nanotube (SWCNT) and multiwall carbon nanotube (MWCNT) of varying diameter with tau protein was investigated by different methods [40]. The circular dichroism bands of the tau protein after concentration variation of SWCNT showed a remarkable increase of $\beta$-sheet content indicating that the binding of tau with SWCNT causes the protein folding and more compact structure of natively unfolded structure of tau protein. Also, as shown in Figure 4, the binding of MWCNT has not altered the secondary structure of tau protein and has resulted in the protein aggregation. This study showed that SWCNT induced stronger interactions with tau protein, causing more pronounced structural changes [40]. Also, transmission electron microscopy (TEM) observation showed that tau protein can bind to the surface of SWCNT thus dispersing it, whereas tau protein cannot attach on the MWCNT surface and eventually ends up in MWCNT agglomeration [40]. Surface functionalization of NPs can also influence the protein adsorption and subsequent NP induced conformational changes. Protein surface residues form an interaction with energetically favorite counterparts on the NP surface based on their charge, hydrophobicity, 
and hydrophilicity [41]. Thermodynamic parameters can stipulate the kind of interaction between protein and NPs namely standard enthalpy change $\left(\Delta \mathrm{H}^{0}\right)$, standard entropy change $\left(\Delta \mathrm{H}^{0}\right)$, standard entropy change $\left(\Delta \mathrm{S}^{0}\right)$, and standard Gibbs free energy change $\left(\Delta \mathrm{G}^{0}\right)$. When $\Delta \mathrm{H}^{0}$ and $\Delta \mathrm{S}^{0}$ are negative, then the main interacting forces between the NP and protein are hydrogen bonds and van der Waals interactions. However, if $\Delta \mathrm{H}^{0}$ is almost zero and $\Delta \mathrm{S}^{0}$ is positive, then the common involving bonds between NP and protein are electrostatic interactions [42].

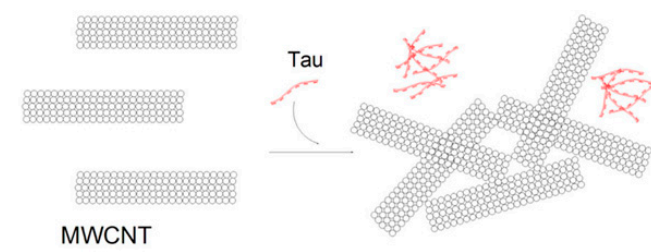

Assembly

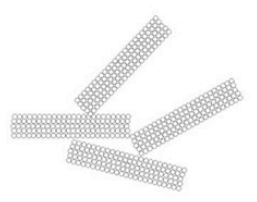

SWCNT
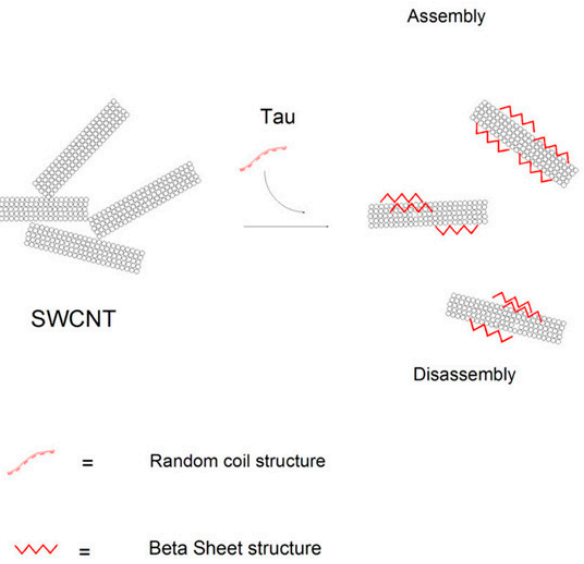

Figure 4. Schematic illustrating single-walled carbon nanotubes (SWCNTs)-induced interactions with tau protein structure, resulting in pronounced conformational changes and corresponding denaturation compared to multi-walled carbon nanotubes (MWCNT) [40].

\subsection{The Effect of Protein Corona on the Toxicity of NPs}

After injection of NPs into the bloodstream, there is a competition between different biological molecules to interact with the surface of NPs (Vermann effect). In the first step, the smallest abundant proteins are adsorbed onto the surface of the NPs, however, over time, they are replaced by proteins with higher affinity [43]. The structure and composition of the protein corona depends on the physicochemical properties of the NPs, the physiological environment and the duration of exposure in that environment. Protein corona changes the size and surface composition of nanomaterials and provides them a new biological identity which determines the physiological responses including aggregation, cellular absorption, and the half-life of NPs in the blood, signaling synthesis, transfer, accumulation and toxicity. The corona on NPs is complex with no general protein corona specific to NPs [44]. Albumin, immunoglobulin G (IgG), fibrinogen, and Apo lipoproteins are found in the corona of all studied NPs; these proteins are prevalent in the blood plasma and hence, over time, may be replaced by proteins with lower concentration but higher affinity on the surface of NPs. Molecules that are weakly attached to the NP and interact with it are soft coronas. NPs with a pre-formed agent group, such as polyethylene glycolated (PEGylated) NPs, contain only one weak covering corona and no hard corona [45]. Protein corona reduces the toxicity of NPs by reducing their cellular absorption. In other words, NPs with less protein corona have more cellular absorption and are thus more cytotoxic. This phenomenon has been reported for CNTs [46], graphene oxide Nano sheets [47] and biopolymer NPs in various cell environments [48]. In the case of common toxic nanomaterials, such as positively charge polystyrene NPs, protein corona has a protective role against membrane damage $[49,50]$. 


\subsection{The Effect of Protein Corona on Non-specific Cellular Uptake}

The specific entry of NPs into the cell is accomplished by a receptor-specific ligand. Non-specific cellular uptake is a random process of the cell performed without bio molecular control. The amount of NP entry into the cell depends on protein corona. The non-specific cellular uptake of oligonucleotidemediated AuNPs has been investigated which showed that their absorption significantly increased in an environment free of serum proteins [51]. Similarly, the cellular absorption of FePt NPs with quantum dots (QDs) is reduced dramatically in HeLa cells through the formation of protein corona [51].

\subsection{The Effect of Protein Corona on Bio-distribution of NPs}

The nature of the NP's core, whether non-polymeric or polymeric, shows that pre-coating increases NP's persistence in the blood and reduces the clearance rate. A study disclosed that the life of bovine serum albumin (BSA)-coated Nano drugs was 6 times more than that of non-coated ones [48].

\subsection{The Effect of Surface Charge of NPs on Their Toxicity}

NP hydrophobicity and surface charge changes the biological distribution of NPs due to their effect on the level of interactions between NPs and the immune system, plasma proteins, extracellular matrix, and non-target cells. Hydrophobic/charged NPs are less persistent in the circulation due to the opsonization of particles by plasma proteins and ultimately by the RES system. Positively charged NPs are attached to negatively charged non-target cells in a non-specific manner; hydrophobic groups on the NP surface induce NP aggregation, which accelerates the identification and relocation by the respiratory (RES) system. In order to reduce this interaction, the surface of the particle is covered with hydrophilic PEG, which reduces the level of opsonization and hence increases particles' persistence in the circulation [52].

\section{The Effects of Physicochemical Properties of NPs on Cytotoxicity}

In fact, a unique property of nanomaterials is their high surface-to-volume ratio which endow them with useful characteristics, but is ironically that trait is also associated with unique mechanisms of toxicity. Toxicity has generally been thought to originate from nanomaterials' size and surface area, composition, shape, and so forth as discussed in the following sections.

\subsection{The Effect of NPs Size on Cytotoxicity}

NP cytotoxicity is affected by changes in NP size [53] and is dependent on the surface-to-volume ratio [54]. Sedimentation velocity, mass diffusivity, attachment efficiency, and deposition velocity depend on the size of the NPs [55]. The size of NPs plays an important role in interacting with the biological system, and it has been revealed that various biological mechanisms such as endocytosis, cellular uptake, and particle processing efficiency in the endocytic path depend on the size of materials [56]. NP size affects the ion release rate, the smaller the size, the faster the release rate and the more the interaction with cell membrane; therefore, it will penetrate into the cell and induces higher toxic effect [57]. In general, size-dependent toxicity of NPs can be related to their ability to enter biological systems.

NP sizes of less than $50 \mathrm{~nm}$ administered through intravenous injection reach the tissues faster than 100-200 nm NPs and exert stronger toxic effects. If the size of NPs is reduced, their contact surface will increase and the level of oxidation and DNA damage will also rise. The size of NPs indicates their pharmaceutical behavior, that is, sizes of less than $50 \mathrm{~nm}$ quickly connect to all tissues and exert toxic effects. NPs larger than $50 \mathrm{~nm}$ are used by the RES, which stops its path to other tissues. But again, organs like the liver and spleen are the main targets of oxidative stress.

The size of NPs has a direct effect on their physiological activity. NPs of size less than $1 \mu \mathrm{m}$ enter the cell and their effects are unknown; those larger than $1 \mu \mathrm{m}$ do not easily enter the cell, but they replace a series of proteins that are absorbed at their surface and react with the cell. Accordingly, 
the NPs size is effective in cell endocytosis [58]. For example, Kim et al. showed that the toxicity of Ag NPs in in vitro model on MC3T3-E1 and PC12 cells is size-dependent. NPs size and dosage affected cell viability as it produced intracellular ROS, LDH release is a useful method for detection of necrosis [59].

\subsection{The effect of NPs Structure and Shape on Cytotoxicity}

NPs come in a variety of shapes, such as spherical, rod-like, filament, and plate-shaped which influences their toxicity [60].

The shape of NPs is effective in the membrane packaging process in endocytosis and phagocytosis [61]; endocytosis of spherical NPs is faster than tubular NPs [62]. Non-spherical NPs are more exposed to blood flow and have more toxic effects.

CNTs can be of single-walled CNTs (SWCNTs) or multi-walled (MWCNTs) class that affect their mechanisms on cell viability; SWCNTs produce more ROSs that MWCNTs [63]. The toxicity of Nano-carbons was found to be dependent on shape and concentration [64]. $\mathrm{TiO}_{2} \mathrm{NPs}_{\text {cause }}$ oxidative damage to DNA, induce lipid peroxidation and micronuclei formation in the presence of light, and these NP-induced effects change with shape [65].

\subsection{The Effect of NPs Surface on Cytotoxicity}

Surface charge of NPs affects biological aspects such as absorption, colloidal behavior, plasma protein binding, and passage through the blood-brain barrier [66]. Negatively charged NPs have more cellular absorption than the positive and neutral NPs due to resistance by plasma proteins, which causes hemolysis and platelet aggregation and eventually toxicity.

NPs surface affects absorption level of ions and biomolecules that may alter cellular response. In addition, surface charge determines the colloid behavior which is the response of the organism to changes in NPs shape and size in the form of cellular accumulation. The effect of surface chemistry of NPs on human immune cells and RBCs in in vivo and in vitro models has been investigated [67]. For instance, the effect of silicon surface charge on cell lines reduced the ATP and genotoxicity for negative hydrophilic and hydrophobic charge relative to hydrophilic, positively charged amine-modified surfaces. The interaction between NPs and cells initially depends on the nature of NPs surface. The incubation of NPs with cells may interfere with cell adhesion, affecting cellular properties such as morphology, cytoskeleton, proliferation, and even survival. Of course, it is worth noting that the surface of NPs and the groups on their surface have a significant effect on adhesion. For example, bare iron oxide NPs with an approximate diameter of $50 \mathrm{~nm}$ have $64 \%$ less cell adhesion compared to polyethylene glycol (PEG) coated ones. This can be due to the difference in the interaction of NPs/cells with different charges in the presence or absence of surface-coating agents, while the metabolism of the nanotube function is different [68].

\subsection{The Effect of NPs Concentration on Cytotoxicity}

The $2 \mathrm{mg} / \mathrm{mL}$ concentration of silicon had a toxic effect on the cell, but no toxic effect was observed in $4 \mathrm{mg} / \mathrm{mL}$ [69]. Varied concentrations of Ag NPs altered mitochondrial function and LDH release; the toxicity changed with changing concentrations, however [9].

\section{In Vivo Study of Nanoparticle Toxicity}

In addition to the numerous study of the behavior of NPs in the in vivo model is being extensively studied. These studies are focused on the biomedical applications of NPs, the NPs toxicity for living organisms remains an important topic. Although NPs are highly promising for difference medical applications, they are potentially side effect. This side effects cannot be estimated exactly in vitro, following from the comparison of the in vivo and in vitro effects of NPs. Metal oxide NPs such as titanium dioxide $\left(\mathrm{TiO}_{2}\right)$ are among the most used NPs, in particular, in environment protection measures. Therefore, it was important to evaluate their toxicity in the bioavailability, in experiments 
with their injection to experimental animals. This study has been performed by Kiss B et al [70]. Experimental animals (rats) were injected with a suspension of $\mathrm{TiO}_{2} \mathrm{NPs}$ at a dose of $15 \mu \mathrm{g} / \mathrm{cm}^{2}$ and their bio distribution, as well as the general condition of the animals, was monitored. The results have shown that the animals have inflammation or another manifestation of a toxic effect observed, within 24 h suggesting that $\mathrm{TiO}_{2}$ NPs are relatively hazardous.

Silver NPs are another example of NPs potentially useful in medicine, because of their antimicrobial activity. Their toxicity and bio distribution were analyzed by Mitra Korani [71] in an experiment where Guiana Pigs were dermal exposure with 100, 1000, 10,000 ppm of silver NPs of different sizes (less than $100 \mathrm{~nm}$ ). The results have shown a close correlation between dermal exposure and tissue levels of Ag NPs was found and tissue with the following ranking: kidney-muscle-bone-skin-liver-heart-spleen (Figure 5). In histopathological studies, severe proximal convoluted tubule degeneration and distal convoluted tubule were seen in the kidneys of the middle and high-dose animals. Separated lines and marrow space narrow were determined as two major signs of bone toxicities which observed in three different dose levels of Ag NPs. Increased dermal dose of Ag NPs caused cardiocyte deformity, congestion and inflammation. The three different Ag NPs concentration gave comparable results for several endpoints measured in heart, bone and kidney, but differed in tissue concentrations and the extent of histopathological changes. It seems that Ag ions could be detected in different organs after dermal exposure, which has the potential to provide target organ toxicities in a time and dose dependent manner.

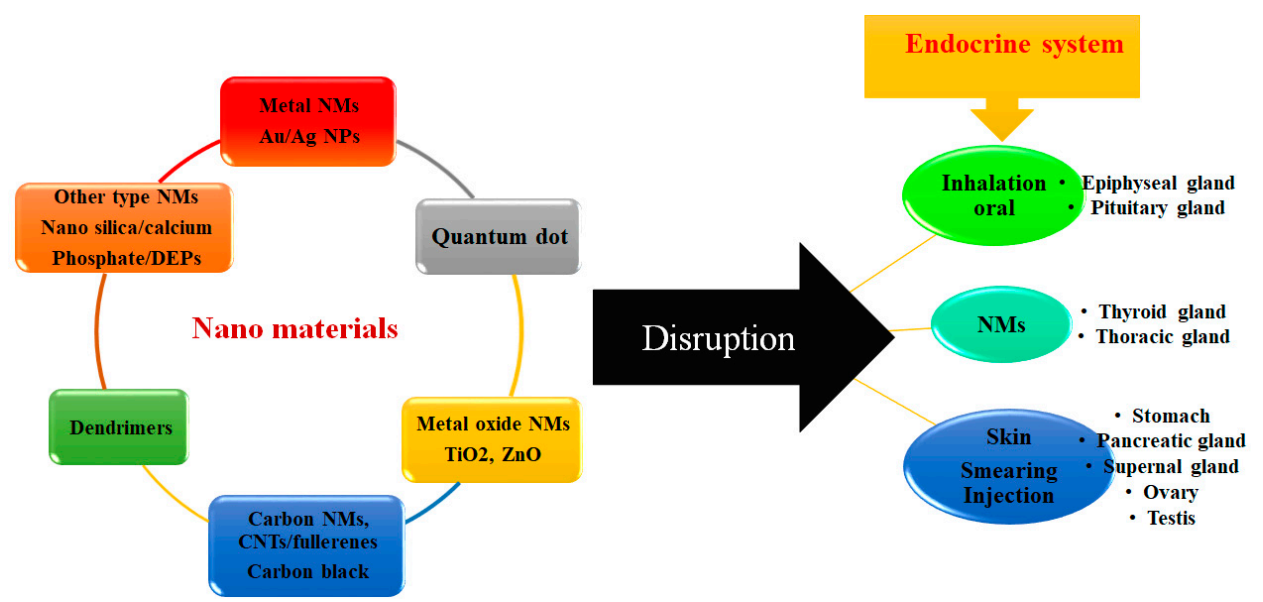

Figure 5. Toxic effects of diverse types of nanoparticles on various organs.

Gold NPs have been shown to be toxic for mice, causing weight loss, decrease in the hematocrit, red blood cell count. In drug delivery using gold NPs, it is also important to know their toxic properties, because the positive effect of their use should overcome over the negative one. Results in one study have been obtained for gelatin NPs modified with polyethylene glycol, which are designed to be used for delivery of ibuprofen sodium salt [72]. The NPs have proved to be nontoxic at the dose that is necessary for effective drug delivery $(1 \mathrm{mg} / \mathrm{Kg})$, which has been confirmed by estimation of inflammatory cytokine levels in the in vivo model, as well as histological analysis of their organs. CNTs are among the nano-carbon structures that, due to their hollow and small structure (smaller than red blood cells), play a special role in the field of medicine, such as drug delivery to target cells, bio-sensoring blood glucose, detecting and destroying cancerous cells, tissue engineering, and so on. Recent studies have shown that CNTs can be used for biological purposes, such as crystallization of proteins, and the production of bioreactors and biosensors. The intrinsic fluorescence properties of nanotubes make them suitable biosensors for identifying specific targets in human body tissues, such as cancer tumors. Numerous methods have now been devised to connect DNA molecules and proteins to the internal and external surfaces of nanotubes; this enhances the ability to target and 
destroy single cancer cells or viral infectious cells [73]. The assembly of special enzymes to nanotubes has resulted in their widespread use as enzymatic biosensors, which allows the identification and measurement of a variety of biological molecules most widely used in the rapid measurement of blood glucose. Recently, the use of CNTs in tissue engineering has attracted the attention of researchers; the key role of CNTs in the culture of tissue cells such as fibroblasts is such an example [73].

Quantum dots are among the NPs that are most promising for medical applications. However, they are potentially side effect for health, because they exhibit various toxic effects in both in vitro and in vivo experiments. The primary application of QDs is now in the field of photography and disintegrating biological compounds. Their additional applications include marking single molecules and optical tracking of their behavior. In these methods, QDs act as chemical marks. Biomolecules, such as antibodies, bind to QDs which makes QDs attach, in a purposeful and specific manner, to target molecules or target cells whose surface is covered by supplemented antigens. The binding of antibodies on the surface of QDs to antigens attached to the surface of these specific cells or proteins results in the emission of light from QDs. If there is no target cell or protein in the sample, no emission will be observed. Therefore, optical tracking of cells or biomolecules is possible over an extended period of time. It should be noted that QDs are extensively used in the detection of cancerous tumors. It passes through the BBB pathway and through trigeminal nerve or olfactory epithelium. CdSe/Zn NPs with a diameter of $13 \mathrm{~nm}$ have the ability to reach tumor tissue in laboratory mice. Six days after the injection, brain nuclei were isolated and Cd was observed in the brain tissue, but there was no indication of astrocyte damage and nerve inflammation. However, the toxicity of this particle for the nerve tissue needs further investigation. QD toxicity is size-dependent; sizes below $20 \mathrm{~nm}$ accumulate in the brain parenchyma. In vitro studies used these NPs to target brain tumors in the cell-line, which in the long term were able to reduce the volume of cancer cells [74]. Similar results were obtained by Zhang et al. [75] where they showed that CdTe QDs predominantly accumulated in the liver, decreasing the amount of antioxidants in it and inducing oxidative stress in liver cells. Cadmium and tellurium ions tend to accumulate in various organs and tissues upon degradation and decay of the cores of CdTe/ZnS QDs.

\section{Study of Toxicity in Cell Cultures}

Many studies of NP toxicity are carried out in cell cultures serving as models of numerous types of human and animal cell. In some cases, cancer cells are used, specially, for the evaluation of toxic effects of NPs used in cancer chemotherapy. The type of cells is selected according to the potential route by which NPs enter the body. This may be oral uptake (mainly by ingestion), transdermal uptake (through the skin surface), inhalation uptake of NPs contained in the breathing air, or intentional NP injection in clinic. Intestinal epithelium cells are often used in experimental models for studying the toxicity of ingested NPs. In in vitro model, the kinetics of NP uptake by cells and the viability of cells upon the NP uptake are studied. The NPs that use in drug delivery, or those used for imaging, are administered by injection. The toxicity of these NPs is studied in primary epithelial cell cultures. Most commonly, an increase in ROS, GSH, IL-1 $\beta$, IL-6, IL-8, and TNF- $\alpha$, are estimated. In addition, various tumor cells (gastrointestinal, human colon, skin, pancreatic PANC-1cells, human lung adenocarcinoma cells, human hepatocellular carcinoma HepG2 cells, human skin carcinoma A431 cells) are used. The toxicity of inhaled NPs is studied using the primary cell lines and different tissues of the respiratory system, including, primary rat brain microvessel endothelial cells (rBMEC), murine neural stem cells (NSCs), human pulmonary cell line (lung adenocarcinoma epithelial A549 cell line), different human epithelial cells and fibroblasts, catla heart cell line (SICH), cardiac microvascular endothelial cells, keratinocyte cell line (HaCaT), human dermal fibroblasts, human immortalized sebaceous gland cell line (SZ95), rat liver derived cell line (BRL 3A), human hepatoblastoma C3A cell line, and embryonic kidney cells (HEK293). The toxicity of the NPs that enter the body trans dermally is usually studied in keratinocytes, fibroblasts, and, more rarely, sebocytes (Table 1). 
Table 1. Toxic effects of nanoparticles on different organs/tissues.

\begin{tabular}{|c|c|c|c|c|c|}
\hline Target & NP & $\begin{array}{l}\text { Concentration, (Size), } \\
\text { (Time), Route of } \\
\text { Administration }\end{array}$ & Major Outcomes & Cell & In Vitro Effect \\
\hline \multirow{8}{*}{ Brain } & \multirow[t]{2}{*}{ AuNP } & $\begin{array}{l}0.8-50 \mu \mathrm{g} / \mathrm{mL},(3,5,7,10 \\
30 \text { and } 60 \mathrm{~nm}),(24 \mathrm{~h})\end{array}$ & $\begin{array}{l}\text { Only the smallest NP tested } \\
(3 \mathrm{~nm}) \text { induced mild signs of } \\
\text { cellular toxicity [76]. }\end{array}$ & $\begin{array}{l}\text { rBMEC (primary rat brain } \\
\text { microvessel endothelial cells) }\end{array}$ & Non-toxic even at highest concentrations in $24 \mathrm{~h}$ [76]. \\
\hline & & $50 \mu \mathrm{g} / \mathrm{mL}(6-120 \mathrm{~h})$ & - & Zebrafish cembryos & $\begin{array}{l}\text { Time- and dose-dependent correlating increases in } \\
\text { permeability and cytotoxicity of cells [77]. }\end{array}$ \\
\hline & $\mathrm{AgNP}$ & $\begin{array}{l}6.25-50 \mu \mathrm{g} / \mathrm{mL},(25,40 \text { or } \\
80 \mathrm{~nm} \text { in size), }(24 \mathrm{~h})\end{array}$ & $\begin{array}{l}\text { Time- and dose-dependent } \\
\text { increase in pro-inflammatory } \\
\text { cytokine release and related } \\
\text { rises in permeability and } \\
\text { cytotoxicity of cells [76]. }\end{array}$ & $\begin{array}{l}\text { rBMEC (primary rat brain } \\
\text { microvessel endothelial cells) }\end{array}$ & $\begin{array}{l}\text { Time- and dose-dependent increase in } \\
\text { pro-inflammatory cytokine release and correlating } \\
\text { increases in permeability and cytotoxicity of cells [78]. }\end{array}$ \\
\hline & $\mathrm{Cu}$ & $30-50 \mathrm{mg} / \mathrm{Kg}$ & $\begin{array}{l}\text { increasing toxicity on } \\
\text { neuromuscular system and } \\
\text { increase NPs penetration of the } \\
\text { blood-brain barrier [78]. }\end{array}$ & - & - \\
\hline & $\mathrm{Al}$ & $30-50 \mathrm{mg} / \mathrm{Kg}$ & $\begin{array}{l}\text { increasing toxicity on } \\
\text { neuromuscular system and } \\
\text { increase NPs penetration of the } \\
\text { blood-brain barrier [78]. }\end{array}$ & - & - \\
\hline & CdSe & $1,10,20 \mathrm{~nm},(24 \mathrm{~h})$ & - & $\begin{array}{l}\text { Primary rat hippocampal neuron } \\
\text { cells in culture }\end{array}$ & Decrease of cells viability [79]. \\
\hline & $\begin{array}{l}\text { Superparamagnetic } \\
\text { iron-oxide } \\
\text { nanoparticles } \\
\text { (SPION) }\end{array}$ & $\begin{array}{l}208 \text { or } 1042 \mu \mathrm{g} / \mathrm{mL} \text { of: } \\
\text { Ferumoxtran-10; } \\
\text { Ferumoxytol }(20-50 \mathrm{~nm}) \text {; } \\
\text { Ferumoxide }(60-185 \mathrm{~nm}) \\
\text { ( } 3 \text { months) }\end{array}$ & $\begin{array}{l}\text { Increasing uptake NPs into the } \\
\text { CNS parenchyma [80]. }\end{array}$ & Murine neural stem cells (NSCs) & $\begin{array}{l}\text { Depleted intracellular glutathione levels, altered } \\
\text { activities of SOD and GPx, hyperpolarization of the } \\
\text { mitochondrial membrane, dissipated cell-membrane } \\
\text { potential and increased DNA damage [81]. }\end{array}$ \\
\hline & $\begin{array}{l}\mathrm{TiO}_{2} \\
\mathrm{ZnO} \\
\mathrm{Fe}_{2} \mathrm{O}_{3} \\
\mathrm{Al}_{2} \mathrm{O}_{3} \\
\mathrm{CrO}_{3}\end{array}$ & $30-45 \mathrm{~nm},(2-72 \mathrm{~h})$ & $\begin{array}{l}\text { leakage of lactate } \\
\text { dehydrogenase (LDH) [82] }\end{array}$ & Neuro-2A & $\begin{array}{l}\text { permeability of NPs in plasma membrane, increasing } \\
\text { apoptosis [82]. }\end{array}$ \\
\hline
\end{tabular}


Table 1. Cont

\begin{tabular}{|c|c|c|c|c|c|}
\hline Target & NP & $\begin{array}{l}\text { Concentration, (Size), } \\
\text { (Time), Route of } \\
\text { Administration }\end{array}$ & Major Outcomes & Cell & In Vitro Effect \\
\hline & $\mathrm{CNT}$ & $\begin{array}{l}\text { PEG-SWCNTs at } \\
\text { concentrations of } 0.5,2.1 \\
\text { and } 1 \mathrm{mg} / \mathrm{mL}\end{array}$ & $\begin{array}{l}\text { Accumulation in the } \\
\text { hippocampus which induces } \\
\text { oxidative stress [83]. }\end{array}$ & PC12 cells & $\begin{array}{l}\text { Decreased mitochondrial membrane potential (MMP), } \\
\text { induced ROS and increased the level of lipid peroxide } \\
\text { and decreased the activities of superoxide dismutase } \\
\text { (SOD), glutathione peroxidase (GSH-Px), catalase (CAT) } \\
\text { and glutathione (GSH) [84]. }\end{array}$ \\
\hline & QD & $\begin{array}{l}0.68 \mathrm{mg} \text { containing } 50 \\
\mathrm{nmol} \text { Cd (13.5 nm in size), } \\
\text { (6 h) Intraperitoneal }\end{array}$ & $\begin{array}{l}\text { Moderately high quantities of } \\
\text { Cd ions was observed in brain } \\
\text { tissue but no signs of } \\
\text { inflammation or parenchymal } \\
\text { damage were detected [74]. }\end{array}$ & Neuron like PC12 cells & Cell death, axonal degeneration [85]. \\
\hline \multirow{4}{*}{ Lung } & AgNP & $\begin{array}{l}515 \mathrm{~g} / \mathrm{m}^{3},(6 \mathrm{~h} / \text { day, } 5 \\
\text { days } / \text { week for } 13 \text { weeks }) \text {, } \\
\text { inhalation }\end{array}$ & $\begin{array}{l}\text { Dose- and time-dependent } \\
\text { increase in blood Ag } \\
\text { nanoparticle concentration was } \\
\text { observed along with correlating } \\
\text { increases in alveolar } \\
\text { inflammation and small } \\
\text { granulomatous lesions [86]. }\end{array}$ & - & - \\
\hline & $\begin{array}{l}\mathrm{Cu} \\
\mathrm{Zn} \\
\mathrm{CO} \\
\mathrm{Sb} \\
\mathrm{Ag} \\
\mathrm{Ni} \\
\mathrm{Fe}\end{array}$ & $\begin{array}{l}0.1-3300 \mu \mathrm{g} / \mathrm{mL} \text {, (3 and } \\
24 \mathrm{~h})\end{array}$ & - & $\begin{array}{l}\text { Human pulmonary cell line (lung } \\
\text { adenocarcinoma epithelial cell } \\
\text { line (A549)) }\end{array}$ & $\begin{array}{l}\text { Mitochondria-dependent cellular apoptosis associated } \\
\text { with ROS [87]. }\end{array}$ \\
\hline & $\mathrm{CuO}$ & $0-40 \mu \mathrm{g} / \mathrm{cm}^{2}$ & - & $\begin{array}{l}\text { Human lung epithelial cells } \\
\text { (A549) }\end{array}$ & $\begin{array}{l}\text { Mitochondria-dependent cellular apoptosis associated } \\
\text { with DNA damage [88]. }\end{array}$ \\
\hline & SPION & 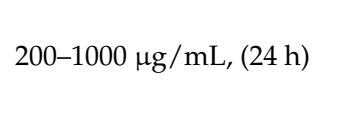 & $\begin{array}{l}\text { Increased cytokines, } \\
\text { inflammation, TNF- } \alpha \text { [89]. }\end{array}$ & $\begin{array}{l}\text { Human lung epithelial cells } \\
\text { (A549) }\end{array}$ & $\begin{array}{l}\text { Activation of JNK, stimulation of tumor necrosis } \\
\text { factor-alpha (TNF } \alpha) \text {, reduction of NF-kB, } \\
\text { increased ROS [90]. }\end{array}$ \\
\hline
\end{tabular}


Table 1. Cont

\begin{tabular}{|c|c|c|c|c|c|}
\hline Target & NP & $\begin{array}{l}\text { Concentration, (Size), } \\
\text { (Time), Route of } \\
\text { Administration }\end{array}$ & Major Outcomes & Cell & In Vitro Effect \\
\hline & SWCNT & $\begin{array}{l}10-100 \mu \mathrm{g} / \mathrm{mL}(24 \mathrm{~h}, 48 \mathrm{~h} \\
\text { and } 72 \mathrm{~h})\end{array}$ & $\begin{array}{l}\text { Dose- and time-dependent } \\
\text { decline in cell viability: up to } \\
50 \% \text { decrease at maximum } \\
\text { dosage after } 72 \text { h. Oxidative } \\
\text { stress was exhibited as a } \\
\text { mechanism of cytotoxicity [91]. }\end{array}$ & $\begin{array}{l}\text { Human lung epithelial cells } \\
\text { (A549) }\end{array}$ & $\begin{array}{l}\text { low acute toxicity was confirmed with the in vivo } \\
\text { model by dispersion of SWCNTs in serum [92]. }\end{array}$ \\
\hline & QD & $12.5 \mu \mathrm{g},(7$ days $)$ & $\begin{array}{l}\text { Increased levels of LDH and } \\
\text { albumin [93]. }\end{array}$ & $\begin{array}{l}\text { Human lung adenocarcinoma } \\
\text { cells }\end{array}$ & $\begin{array}{l}\text { Mitochondria-dependent cellular apoptosis associated } \\
\text { with decrease of cells viability [94]. }\end{array}$ \\
\hline \multirow{4}{*}{ Heart } & AgNPs & $\begin{array}{l}100,1000 \text { and } 10,000 \mathrm{ppm}, \\
\text { (period of } 13 \text { weeks) }\end{array}$ & $\begin{array}{l}\text { increasing cardiocyte deformity, } \\
\text { congestion and } \\
\text { inflammation [71]. }\end{array}$ & Catla heart cell line $(\mathrm{SICH})$ & $\begin{array}{l}\text { Increased lipid peroxidation (LPO) level and decreased } \\
\text { level of GSH, SOD and CAT [95]. }\end{array}$ \\
\hline & Iron oxide NPs & $\begin{array}{l}100,200,300 \text { and } 500 \\
\mu \mathrm{g} / \mathrm{mL},(\text { period of } 2 \\
\text { weeks) }\end{array}$ & $\begin{array}{l}\text { Showed that baseline maximal } \\
\text { oxidative capacities were } \\
\text { proteins in the heart [96]. }\end{array}$ & $\begin{array}{l}\text { Cardiac microvascular } \\
\text { endothelial cells }\end{array}$ & $\begin{array}{l}\text { Induced a concentration- and time-dependent } \\
\text { cytotoxicity with decrease of cells viability }\end{array}$ \\
\hline & CNT & $1-0.3 \mathrm{mg} / \mathrm{Kg}$ body weight & $\begin{array}{l}\text { Blocks potassium channels. The } \\
\text { suppressed and inhibited IK } \\
\text { and potassium channels lead to } \\
\text { increased heart rate [97]. }\end{array}$ & Microvascular Endothelial Cells & $\begin{array}{l}\text { Dose- and time-dependent increasing DNA } \\
\text { damage [98]. }\end{array}$ \\
\hline & QD & - & - & $\begin{array}{l}\text { Human hepatocellular carcinoma, } \\
\text { HepG2 cells }\end{array}$ & $\begin{array}{l}\text { Mitochondria-dependent cellular apoptosis associated } \\
\text { with ROS [99]. }\end{array}$ \\
\hline \multirow{3}{*}{ Dermal } & $\mathrm{AgNP}$ & 50 and $100 \mu \mathrm{g} / \mathrm{mL},(24 \mathrm{~h})$ & $\begin{array}{l}\text { Mitochondria-dependent } \\
\text { cellular apoptosis related to } \\
\text { ROS at a concentration of } \\
\geq 50 \mu \mathrm{g} / \mathrm{mL} \text { [100]. }\end{array}$ & A431 (human skin carcinoma) & $\begin{array}{l}\text { No evidence for Cellular damage up to a concentration } \\
\text { of } 6.25 \mathrm{~g} / \mathrm{mL} \text {. Morphological changes at concentrations } \\
\text { between } 6.25 \text { and } 50 \mathrm{~g} / \mathrm{mL} \text { with concomitant rise in } \\
\text { GSH, SOD and lipid peroxidation. } \\
\text { DNA fragmentation suggests cell death by } \\
\text { apoptosis [101]. }\end{array}$ \\
\hline & $\mathrm{TiO}_{2}$ & $15 \mu \mathrm{g} / \mathrm{cm}^{2},(24 \mathrm{~h})$ & $\begin{array}{l}\text { Cytotoxicity was detected to be } \\
\text { apoptosis [101]. }\end{array}$ & $\begin{array}{l}\text { HaCaT (keratinocyte cell line), } \\
\text { human dermal fibroblasts, } \\
\text { human immortalized sebaceous } \\
\text { gland cell line (SZ95) }\end{array}$ & $\begin{array}{l}\text { Cytotoxicity was observed to be affecting cellular } \\
\text { functions such as cell proliferation, differentiation and } \\
\text { mobility resulting in apoptosis [70]. }\end{array}$ \\
\hline & $\mathrm{Fe}_{3} \mathrm{O}_{4}$ & $65 \mathrm{~nm}$ & - & Skin tumor cells & Increases ROS, deceasing cancer cells [102]. \\
\hline
\end{tabular}


Table 1. Cont

\begin{tabular}{|c|c|c|c|c|c|}
\hline Target & NP & $\begin{array}{l}\text { Concentration, (Size), } \\
\text { (Time), Route of } \\
\text { Administration }\end{array}$ & Major Outcomes & Cell & In Vitro Effect \\
\hline & $\mathrm{CNT}$ & $10 \mu \mathrm{g} / \mathrm{mL},(72 \mathrm{~h})$ & $\begin{array}{l}\text { NPs increased relatively IL8 } \\
\text { and ROS factors in } \\
\text { animal [103]. }\end{array}$ & Human Dermal Fibroblast Cells & $\begin{array}{l}\text { Mitochondria-dependent cellular apoptosis associated } \\
\text { with decrease cell viability [104]. }\end{array}$ \\
\hline & QD & $\begin{array}{l}4.6 \mathrm{~nm} \text { core/shell } \\
\text { diameter QD for } 8 \mathrm{~h} \\
\text { and } 24 \mathrm{~h}\end{array}$ & $\begin{array}{l}\text { Increased IL-1b, IL-6, } \\
\text { and IL-8 [105]. }\end{array}$ & $\begin{array}{l}\text { Human epidermal keratinocytes } \\
\text { (HEKs) }\end{array}$ & Increased IL-1 $\beta$, IL-6, IL-8, and TNF- $\alpha$ factors [106]. \\
\hline \multirow{7}{*}{ Liver } & AgNPs & $\begin{array}{l}\text { 10, 50, } 100,150,200,400 \\
\text { ppm for } 24 \mathrm{~h}\end{array}$ & - & $\begin{array}{l}\text { Primary mouse fibroblasts, } \\
\text { primary hepatocytes }\end{array}$ & $\begin{array}{l}\text { Production of mediators of oxidative-stress. } \\
\text { increase GSH [107]. }\end{array}$ \\
\hline & CdSe & $62.5-1000 \mu \mathrm{g} / \mathrm{mL},(1-8 \mathrm{~h})$ & - & Primary rat hepatocytes & $\begin{array}{l}\text { Evidence for cellular damage up to a concentration of } \\
62.5 \mu \mathrm{g} / \mathrm{mL} \text { with concomitant rise in GSH, SOD and } \\
\text { lipid peroxidation [108]. }\end{array}$ \\
\hline & $\mathrm{ZnO} N P s$ & $\begin{array}{l}100,300 \text { and } 600 \mathrm{mg} / \mathrm{Kg}, \\
\text { ( } 7 \text { days) }\end{array}$ & - & Human hepatocyte (L02) & $\begin{array}{l}\text { Mitochondria-dependent cellular apoptosis associated } \\
\text { with ROS, reduction of SOD, depletion of GSH, } \\
\text { and oxidative DNA damage [91]. }\end{array}$ \\
\hline & $\mathrm{Al}_{2} \mathrm{O}_{3}$ & $235,245 \mathrm{ppm}$ & $\begin{array}{l}\text { Blood cell and melanoma } \\
\text { macrophage accumulation, } \\
\text { hepatocyte necrosis, vaculation } \\
\text { and portal vein alteration [109]. }\end{array}$ & - & - \\
\hline & $\mathrm{TiO}_{2}$ & $\begin{array}{l}5,10,50,100 \text { or } 150 \\
\mathrm{mg} / \mathrm{Kg} \text {, (daily for } 14 \\
\text { days) }\end{array}$ & $\begin{array}{l}\text { NPs increased relatively IL-8 } \\
\text { and ROS factors in } \\
\text { animal [110]. }\end{array}$ & $\begin{array}{l}\text { Rat liver derived cell line } \\
\text { (BRL 3A) }\end{array}$ & $\begin{array}{l}\text { Mitochondria-dependent cellular apoptosis associated } \\
\text { with ROS, reduction of SOD, depletion of GSH, } \\
\text { and oxidative DNA damage [9]. }\end{array}$ \\
\hline & CNT & $\sim 25 \mu \mathrm{g} / \mathrm{cm}^{2}$ & $\begin{array}{l}\text { NPs increased relatively } \\
\text { apoptosis factor in animal [111]. }\end{array}$ & $\begin{array}{l}\text { Human hepatoblastoma C3A } \\
\text { cell line }\end{array}$ & $\begin{array}{l}\text { Mitochondria-dependent cellular apoptosis associated } \\
\text { with ROS, IL8, reduction of SOD, depletion of GSH, } \\
\text { and oxidative DNA damage [112]. }\end{array}$ \\
\hline & QDs & $1000 \mu \mathrm{g} / \mathrm{mL},(24 \mathrm{~h})$ & $\begin{array}{l}\text { NPs increased relatively ROS } \\
\text { in liver [113]. }\end{array}$ & Primary rat hepatocytes & $\begin{array}{l}\text { Cytotoxicity was thought to be due to the release of free } \\
\text { cadmium ions [108]. }\end{array}$ \\
\hline
\end{tabular}


Table 1. Cont

\begin{tabular}{|c|c|c|c|c|c|}
\hline Target & NP & $\begin{array}{l}\text { Concentration, (Size), } \\
\text { (Time), Route of } \\
\text { Administration }\end{array}$ & Major Outcomes & Cell & In Vitro Effect \\
\hline \multirow{6}{*}{ Kidney } & AuNPs & $\begin{array}{l}5,10,100 \text { ppm, } \\
\text { (via IP injection for } \\
7 \text { successive days) }\end{array}$ & $\begin{array}{l}\text { Increase levels of CREA, UREA, } \\
\text { total bilirubin ALP in rats' } \\
\text { blood serum were examined to } \\
\text { show a degree of kidney } \\
\text { functionality [114]. }\end{array}$ & $\begin{array}{l}\text { Embryonic kidney cells } \\
\text { (HEK293). }\end{array}$ & $\begin{array}{l}\text { Toxicity was dose dependent. In a dose of } 44 \mathrm{mg} / \mathrm{mL} \\
\text { for } 4 \mathrm{~h} \text {, toxicity was observed on } \\
\text { DNA/transferrin [115]. }\end{array}$ \\
\hline & ZnO NPs & $\begin{array}{l}100,300 \text { and } 1000 \mathrm{mg} / \mathrm{Kg} \\
\text { in } 2 \text { weeks }\end{array}$ & $\begin{array}{l}\text { Significant increase in serum } \\
\text { creatinine and blood urea } \\
\text { nitrogen, decrease in } \\
\text { hemoglobin, haematocrit and } \\
\text { mean corpuscular hemoglobin } \\
\text { concentration [116]. }\end{array}$ & $\begin{array}{l}\text { Human embryonic kidney } \\
\text { (HEK293) cells }\end{array}$ & $\begin{array}{l}\text { Lead to cellular morphological modifications, } \\
\text { mitochondrial dysfunction, and cause reduction of SOD, } \\
\text { depletion of GSH, and oxidative DNA damage [91]. }\end{array}$ \\
\hline & $\mathrm{CuONPs}$ & $\begin{array}{l}\text { A dose of } 10 \mathrm{mg} / \mathrm{Kg} \text { three } \\
\text { times a week up to } \\
19 \text { injections }\end{array}$ & $\begin{array}{l}\text { Toxicity showed with DNA } \\
\text { fragmentation [117]. }\end{array}$ & Embryonic kidney cells (HEK293) & Increased ROS, decreased cell viability [118] \\
\hline & $\mathrm{TiO}_{2}$ & $1,10,100 \mu \mathrm{g} / \mathrm{mL}$ & Embryonic kidney cells & - & DNA damage and genomic toxicity [119]. \\
\hline & CNT & $4 \mathrm{mg} / \mathrm{Kg}$, (7 days) & $\begin{array}{l}\text { Increase level of IL-8, } \\
\text { LDH and lipid peroxidation } \\
\text { in serum [120]. }\end{array}$ & Embryonic kidney cells (HEK293) & $\begin{array}{l}\text { Decreased cell viability, increase cell membrane } \\
\text { damage, LDH release, reduced glutathione (GSH), } \\
\text { interleukin-8 (IL-8), lipid peroxidation [121] }\end{array}$ \\
\hline & QD & $\begin{array}{l}1.5 \mu \mathrm{mol} / \mathrm{Kg},(1,7,14, \\
\text { and } 28 \text { days })\end{array}$ & - & Embryonic kidney cells (HEK293) & $\begin{array}{l}\text { Time-dependent decrease of mitochondrial } \\
\text { transmembrane potential, up regulate Bcl-2 expression, } \\
\text { alleviated apoptosis [122]. }\end{array}$ \\
\hline \multirow[t]{2}{*}{ Spleen } & AgNPs & $\begin{array}{l}30,300 \text { and } 1000 \mathrm{mg} / \mathrm{Kg} \\
\text { doses of } \mathrm{AgNPs}(60 \mathrm{~nm}) \text {, } \\
28 \text { days of oral } \\
\text { administration }\end{array}$ & $\begin{array}{l}\text { Ag induces the permeability of } \\
\text { cell membrane to potassium } \\
\text { and sodium and interrupts the } \\
\text { activity of Na-K-ATPase and } \\
\text { mitochondria. Inhibition of } \\
\text { NF-kB activity, a decrease in } \\
\text { expression bcl-2, increase in } \\
\text { caspase-3 expression }[123,124] \text {. }\end{array}$ & - & - \\
\hline & $\mathrm{Fe}_{2} \mathrm{O}_{3}$ & $\begin{array}{l}0.1,0.5 \text { and } 1.0 \mathrm{mg} / \mathrm{L} \\
\left(9.2 \times 10^{-4}, 4.6 \times 10^{-3}\right. \\
\left.\text { and } 9.2 \times 10^{-3} \mathrm{mM}\right) \\
\text { aqueous suspensions for } \\
60 \text { days }\end{array}$ & $\begin{array}{l}\text { Accumulated in the spleen } \\
\text { organ and induce acute } \\
\text { toxicity [125]. }\end{array}$ & - & - \\
\hline
\end{tabular}


Table 1. Cont.

\begin{tabular}{|c|c|c|c|c|c|}
\hline Target & NP & $\begin{array}{l}\text { Concentration, (Size), } \\
\text { (Time), Route of } \\
\text { Administration }\end{array}$ & Major Outcomes & Cell & In Vitro Effect \\
\hline & CNT & $\begin{array}{l}1.5 \mathrm{~mL} ; 2 \mathrm{mg} \text { multi-walled } \\
\text { (MW) CNT per body } \\
\text { weight (bw), } \\
(1,6,24,48 \text { and } 144 \mathrm{~h})\end{array}$ & $\begin{array}{l}\text { After i.p. administration, } \\
\text { MWCNT translocate } \\
\text { progressively in the spleen, } \\
\text { with a peak of concentration } \\
\text { after } 48 \mathrm{~h} \text {, and determine } \\
\text { lymphoid hyperplasia and an } \\
\text { increase in the number of cells } \\
\text { which undergo apoptosis, in } \\
\text { parallel with the enhancement } \\
\text { of the mitosis in the white pulp } \\
\text { and with transient alterations of } \\
\text { oxidative stress and } \\
\text { inflammation [126]. }\end{array}$ & - & - \\
\hline & QD & $6000 \mathrm{~g}$ for $10 \mathrm{~min}$ & $\begin{array}{l}\text { Distribution in different body } \\
\text { organs and aggregation in } \\
\text { spleen [127-129] }\end{array}$ & - & - \\
\hline \multirow{7}{*}{ Stomach } & AgNPs & $\begin{array}{l}\text { 28-day repeated oral dose } \\
\text { of } \mathrm{AgNPs} \text { of } 60 \mathrm{~nm} \text {, } \\
2.6 \mathrm{mg} \mathrm{Ag} / \mathrm{Kg} \mathrm{b.w./day}\end{array}$ & $\begin{array}{l}\text { Aggregation in stomach } \\
\text { tissues [130]. }\end{array}$ & - & - \\
\hline & $\mathrm{Au}$ NPs & - & - & Gastrointestinal cancer cells & Removing tumor cells from healthy cells [131]. \\
\hline & CdSe & $0.84 \times 10^{5} \mu \mathrm{m}$ & - & Human colon carcinoma cell line & Removing tumor cells from healthy cells [132]. \\
\hline & $\mathrm{TiO}_{2} \mathrm{NPs}$ & $\begin{array}{l}1012 \text { particles/person per } \\
\text { day in } 2 \text { weeks }\end{array}$ & $\begin{array}{l}\text { Aggregation in stomach } \\
\text { tissues [133]. }\end{array}$ & - & - \\
\hline & $\mathrm{ZnO} N \mathrm{NP}$ & $\begin{array}{l}5,50,300,1000 \text { and } \\
2000 \mathrm{mg} / \mathrm{Kg} \text { b.w }\end{array}$ & $\begin{array}{l}\text { Aggregation in stomach } \\
\text { tissues [134]. }\end{array}$ & - & - \\
\hline & CNT & $<5 \mu \mathrm{m}, 10-20 \mu \mathrm{m},(7$ days $)$ & Inflammation [135-138] & - & - \\
\hline & QD & 2 to $200 \mathrm{nmol} / \mathrm{mL},(24 \mathrm{~h})$ & $\begin{array}{l}\text { NPs increased relativel ROS } \\
\text { factors in animal [139] }\end{array}$ & - & - \\
\hline \multirow[b]{2}{*}{ Pancreas } & Ag NPs & $\begin{array}{l}\text { AgNPs }(100 \mu \mathrm{g} / \mathrm{mL}) \\
(24 \mathrm{~h})\end{array}$ & $\begin{array}{l}\text { NPs increased relatively ROS } \\
\text { factors in animal [140]. }\end{array}$ & Pancreas cancer BxPC-3 Cells & $\begin{array}{l}\text { Inhibition of NF-kB activity, a decrease in bcl-2, and an } \\
\text { increase in caspase-3 and survivin expression [141]. }\end{array}$ \\
\hline & AuNPs & $\begin{array}{l}50 \mathrm{~nm}, 2.5 \mathrm{mg} / \mathrm{Kg} \text {, Male } \\
\text { Wistar diabetic with } \\
\text { autism spectrum disorder } \\
\text { pups, i.p. } 7 \text { day }\end{array}$ & $\begin{array}{l}\text { NPs increased relatively ROS } \\
\text { factors in animal [142] }\end{array}$ & - & - \\
\hline
\end{tabular}


Table 1. Cont.

\begin{tabular}{|c|c|c|c|c|c|}
\hline Target & NP & $\begin{array}{l}\text { Concentration, (Size), } \\
\text { (Time), Route of } \\
\text { Administration }\end{array}$ & Major Outcomes & Cell & In Vitro Effect \\
\hline & cobalt ferrite NPs & - & - & human pancreatic cancer cells & Accumulation in cells increasing apoptosis [143]. \\
\hline & $\mathrm{ZnO} N \mathrm{NP}$ & $\begin{array}{l}0,500,1000, \text { and } 2000 \\
\mathrm{mg} / \mathrm{Kg} / \text { day for } 14 \text { days. }\end{array}$ & $\begin{array}{l}\text { Decreased body weight, feed } \\
\text { consumption, alterations in } \\
\text { blood factors (HB, HCT, MCV, } \\
\text { MCH, MCHC, and LYM) and } \\
\text { increase in blood cells (WBCs } \\
\text { and NEUs), and } \\
\text { histopathological alterations in } \\
\text { the pancreas [144]. }\end{array}$ & - & - \\
\hline & $\mathrm{TiO}_{2}$ & 42 days & - & Pancreatic cancer cells (PANC-1) & Tumor growth inhibition and induce cell toxicity [145]. \\
\hline & CNT & 5,10 and $50 \mu \mathrm{g} / \mathrm{mL}$ & - & Pancreatic cancer cells (PANC-1) & Hyperthermia; necrosis of malignant cells [146] \\
\hline & QD & $0.2 \mathrm{~mL},(7 \mathrm{~h})$ & $\begin{array}{l}\text { NPs increased relatively ROS } \\
\text { factors in animal organ [147]. }\end{array}$ & - & - \\
\hline \multirow{4}{*}{ Ear } & AgNPs & $\begin{array}{l}4000 \mu \mathrm{g} / \mathrm{mL} \text { AgNPs } \\
\text { induced }\end{array}$ & $\begin{array}{l}\text { Hearing loss with partial } \\
\text { recovery within } 7 \text { days and } \\
\text { increasing ROS in animal organ } \\
\text { [148]. }\end{array}$ & $\mathrm{BALB} / \mathrm{c} 3 \mathrm{~T} 3$ cell line & Impairment of the mitochondrial function [148]. \\
\hline & SPION & $\begin{array}{l}150 \mu \mathrm{L} \text { of } 15 \mathrm{mg} / \mathrm{mL}, \\
(1-4 \mathrm{~h}, 4 \text { and } 7 \text { days })\end{array}$ & $\begin{array}{l}\text { Uptake into the CNS } \\
\text { parenchyma [149]. }\end{array}$ & - & - \\
\hline & $\mathrm{CNT}$ & $\begin{array}{l}150 \mu \mathrm{L} \text { of } 15 \mathrm{mg} / \mathrm{mL} \\
(1,2,4 \mathrm{~h}, 4 \text { and } 7 \text { days }\end{array}$ & $\begin{array}{l}\text { Accumulation in CNS } \\
\text { parenchyma. No pathological } \\
\text { alterations were observed [150]. }\end{array}$ & - & - \\
\hline & QD & $\begin{array}{l}1 \mathrm{mg} / \mathrm{mL} \text { or } 4.5 \mathrm{mg} / \mathrm{mL}) \\
(24 \mathrm{~h})\end{array}$ & $\begin{array}{l}\text { Limb abnormalities, body wall } \\
\text { defects, neural tube } \\
\text { defects [150]. }\end{array}$ & - & - \\
\hline \multirow[t]{2}{*}{ Eye } & AuNPs & 2, 20 and $200 \mathrm{~nm}, 72 \mathrm{~h}$ & $\begin{array}{l}\text { NPs increased relatively ROS } \\
\text { factors in animal [151]. }\end{array}$ & Human corneal cells & $\begin{array}{l}\text { Increasing apoptosis and aberrant expression factor } \\
\text { pigmentation, development (pax6a, pax6b, otx2, } \\
\text { and rx1) and pigmentation (sox10) [151]. }\end{array}$ \\
\hline & Iron oxide & 2, 20 and $200 \mathrm{~nm},(72 \mathrm{~h})$ & $\begin{array}{l}\text { NPs increased relatively ROS } \\
\text { factors in animal [151]. }\end{array}$ & - & - \\
\hline
\end{tabular}


Table 1. Cont

\begin{tabular}{|c|c|c|c|c|c|}
\hline Target & NP & $\begin{array}{l}\text { Concentration, (Size), } \\
\text { (Time), Route of } \\
\text { Administration }\end{array}$ & Major Outcomes & Cell & In Vitro Effect \\
\hline & Silica NPs & 50,100 and $150 \mathrm{~nm},(48 \mathrm{~h})$ & $\begin{array}{l}\text { NPs increased relatively ROS in } \\
\text { cell [152]. }\end{array}$ & - & - \\
\hline & CNT & $\begin{array}{l}\text { Up to } 750 \mathrm{~nm} \text { every week } \\
\text { for } 9 \text { weeks }\end{array}$ & $\begin{array}{l}\text { Eye-irritation, retinal } \\
\text { degeneration [74]. }\end{array}$ & - & - \\
\hline & QD & $\begin{array}{l}17 \text { weeks of age, in the } \\
\text { range of } 2.7-3.6 \mathrm{Kg} \text { in } \\
\text { body weight }\end{array}$ & $\begin{array}{l}\text { Eye-irritation, retinal } \\
\text { degeneration [153]. }\end{array}$ & - & - \\
\hline
\end{tabular}




\section{Conclusions}

Nanoparticles have many biomedical applications due to their unique characteristics such as size, shape, chemistry and charge. However, the signaling pathways through which NPs can produce toxic effects need to be understood better. Recent studies have shown that inflammation, necrosis, ROS and apoptosis are key factors that mediate the mechanism of toxicity of NPs. These results may create a barrier to the use of NPs in diagnosis and in the treatment of diseases for which they are ideally suited. It is important to identify the dose, shape, and the properties of NPs that are responsible for their toxicity in order to reduce their side effect by appropriately modifying the formulation or to use a NP with lower toxicity. The dose of NPs is an important factor in their toxicological profile, along with their accumulation, distribution, metabolism and disposal. In line with this, intravenously injected NPs have a higher toxicity than those administered to the skin. According to the results of various studies, there should be protocols that show which doses and what structures of NPs are more toxic. In general, the problems in the evaluation of NP toxicity are due to the disparity between different toxicological studies performed on the NPs of diverse origins and make-up. Accordingly, the study of NP toxicity in various applications, especially biomedicine applications such as drug delivery, bio-security and NP toxicity, is very crucial. Consequently, there is a need for the development of accepted and specific protocols to identify the actual particle with its surface surroundings and the composition of NPs that renders them toxic. It is hoped that our increased knowledge of NPs lead to their safer design with reduced toxicity so that they can be used for treatment of assorted diseases and drug delivery.

Author Contributions: M.A.; M.A.M.; M.R.; M.F. and M.M. wrote the manuscript and contributed in conceptualization of the work. A.M.; S.J. and R.S.V. provided ideas and critically edited the entire composition of the manuscript.

Acknowledgments: A.M. appreciates financial support from National Institute of Genetic Engineering and Biotechnology. M.R. is financially supported by Tehran University of Medical Sciences grants. R.M. is thankful for the financial support from Kerman University of medical sciences. M.A. is financially supported by Iran University of Medical Sciences grants.

Conflicts of Interest: The authors declare no conflict of interest.

\section{Abbreviations}

$\begin{array}{ll}\text { AD } & \text { Albumin Derivatized } \\ \text { BBB } & \text { Blood-Brain-Barrier } \\ \text { BMECs } & \text { Brain Microvascular Endothelial Cells } \\ \text { CNS } & \text { Central Nervous System } \\ \text { CSF } & \text { Cerebrospinal Fluid } \\ \text { DD } & \text { Dextran Derivatized } \\ \text { Ag NP } & \text { Silver Nanoparticle } \\ \text { DA } & \text { Dopamine } \\ \text { Au NP } & \text { Gold Nanoparticles } \\ \text { MRI } & \text { Magnetic Resonance Imaging } \\ \text { CNTs } & \text { Carbon nano tubes } \\ \text { MWCNTs } & \text { Multi-Walled Carbon Nanotubes } \\ \text { NPs } & \text { Nanoparticles } \\ \text { QDs } & \text { Quantum Dots } \\ \text { SWCNTs } & \text { Single-Walled Carbon Nanotubes } \\ \text { SPIONs } & \text { Superparamagnetic Iron Oxide Nanoparticles } \\ \text { USPIONs } & \text { Ultra-Small Superparamagnetic Iron Oxide Nanoparticles }\end{array}$




\section{References}

1. Cheng, R.; Feng, F.; Meng, F.; Deng, C.; Feijen, J.; Zhong, Z. Glutathione-responsive nano-vehicles as a promising platform for targeted intracellular drug and gene delivery. J. Control. Release 2011, 152, 2-12. [CrossRef] [PubMed]

2. Sajid, M.; Ilyas, M.; Basheer, C.; Tariq, M.; Daud, M.; Baig, N.; Shehzad, F. Impact of nanoparticles on human and environment: Review of toxicity factors, exposures, control strategies, and future prospects. Environ. Sci. Pollut. Res. 2015, 22, 4122-4143. [CrossRef] [PubMed]

3. Dwivedi, A.D.; Dubey, S.P.; Sillanpää, M.; Kwon, Y.-N.; Lee, C.; Varma, R.S. Fate of engineered nanoparticles: Implications in the environment. Coord. Chem. Rev. 2015, 287, 64-78. [CrossRef]

4. Ajdari, M.; Ghahnavieh, M.Z. Histopathology effects of nickel nanoparticles on lungs, liver, and spleen tissues in male mice. Int. Nano Lett. 2014, 4, 113. [CrossRef]

5. Negahdary, M.; Ajdary, M. The toxicity of gold, silver, and zinc oxide nanoparticles on LDH enzyme in male mice. Annu. Res. Rev. Biol. 2014, 4, 1346-1352. [CrossRef]

6. Hornos Carneiro, M.F.; Barbosa, F., Jr. Gold nanoparticles: A critical review of therapeutic applications and toxicological aspects. J. Toxic. Environ. Health 2016, 19, 129-148. [CrossRef] [PubMed]

7. Moulton, M.C.; Braydich-Stolle, L.K.; Nadagouda, M.N.; Kunzelman, S.; Hussain, S.M.; Varma, R.S. Synthesis, characterization and biocompatibility of "green" synthesized silver nanoparticles using tea polyphenols. Nanoscale 2010, 2, 763-770. [CrossRef] [PubMed]

8. Warheit, D.B.; Laurence, B.R.; Reed, K.L.; Roach, D.H.; Reynolds, G.A.; Webb, T.R. Comparative pulmonary toxicity assessment of single-wall carbon nanotubes in rats. Toxicol. Sci. 2004, 77, 117-125. [CrossRef] [PubMed]

9. Hussain, S.; Hess, K.; Gearhart, J.; Geiss, K.; Schlager, J. In vitro toxicity of nanoparticles in BRL 3A rat liver cells. Toxicol. In Vitro 2005, 19, 975-983. [CrossRef] [PubMed]

10. Kang, S.J.; Kim, B.M.; Lee, Y.J.; Chung, H.W. Titanium dioxide nanoparticles trigger p53-mediated damage response in peripheral blood lymphocytes. Environ. Mol. Mutagen. 2008, 49, 399-405. [CrossRef] [PubMed]

11. Xia, T.; Kovochich, M.; Brant, J.; Hotze, M.; Sempf, J.; Oberley, T.; Sioutas, C.; Yeh, J.I.; Wiesner, M.R.; Nel, A.E. Comparison of the abilities of ambient and manufactured nanoparticles to induce cellular toxicity according to an oxidative stress paradigm. Nano Lett. 2006, 6, 1794-1807. [CrossRef] [PubMed]

12. Muller, J.; Huaux, F.; Moreau, N.; Misson, P.; Heilier, J.-F.; Delos, M.; Arras, M.; Fonseca, A.; Nagy, J.B.; Lison, D. Respiratory toxicity of multi-wall carbon nanotubes. Toxic. Appl. Pharmacol. 2005, 207, 221-231. [CrossRef] [PubMed]

13. Mutlu, G.k.M.; Budinger, G.S.; Green, A.A.; Urich, D.; Soberanes, S.; Chiarella, S.E.; Alheid, G.F.; McCrimmon, D.R.; Szleifer, I.; Hersam, M.C. Biocompatible nanoscale dispersion of single-walled carbon nanotubes minimizes in vivo pulmonary toxicity. Nano Lett. 2010, 10, 1664-1670. [CrossRef] [PubMed]

14. Fard, J.K.; Jafari, S.; Eghbal, M.A. A review of molecular mechanisms involved in toxicity of nanoparticles. Adv. Pharm. Bull. 2015, 5, 447-454. [CrossRef] [PubMed]

15. Gualtierotti, R.; Guarnaccia, L.; Beretta, M.; Navone, S.E.; Campanella, R.; Riboni, L.; Rampini, P.; Marfia, G. Modulation of neuroinflammation in the central nervous system: Role of chemokines and sphingolipids. Adv. Ther. 2017, 34, 396-420. [CrossRef] [PubMed]

16. Ma, L.; Zou, X.; Chen, W. A new X-ray activated nanoparticle photosensitizer for cancer treatment. J. Biomed. Nanotechnol. 2014, 10, 1501-1508. [CrossRef] [PubMed]

17. Guan, X.; Avci-Adali, M.; Alarçin, E.; Cheng, H.; Kashaf, S.S.; Li, Y.; Chawla, A.; Jang, H.L.; Khademhosseini, A. Development of hydrogels for regenerative engineering. Biotechnol. J. 2017, 12, 1600394. [CrossRef] [PubMed]

18. Dorniani, D.; Hussein, M.Z.B.; Kura, A.U.; Fakurazi, S.; Shaari, A.H.; Ahmad, Z. Preparation of $\mathrm{Fe}_{3} \mathrm{O}_{4}$ magnetic nanoparticles coated with gallic acid for drug delivery. Int. J. Nanomed. 2012, 7, 5745-5756. [CrossRef] [PubMed]

19. Benita, S. Microencapsulation: Methods and Industrial Applications; Taylor \& Francis: Boca Raton, FL, USA, 2006.

20. Mishra, A.K. Nanomedicine for Drug Delivery and Therapeutics; Wiley: New York, NY, USA, 2013.

21. Sharma, V.K.; Filip, J.; Zboril, R.; Varma, R.S. Natural inorganic nanoparticles-formation, fate, and toxicity in the environment. Chem. Soc. Rev. 2015, 44, 8410-8423. [CrossRef] [PubMed] 
22. You, Y.; He, L.; Ma, B.; Chen, T. High-drug-loading mesoporous silica nanorods with reduced toxicity for precise cancer therapy against nasopharyngeal carcinoma. Adv. Funct. Mater. 2017, 27, 1703313. [CrossRef]

23. Coradeghini, R.; Gioria, S.; García, C.P.; Nativo, P.; Franchini, F.; Gilliland, D.; Ponti, J.; Rossi, F. Size-dependent toxicity and cell interaction mechanisms of gold nanoparticles on mouse fibroblasts. Toxicol. Lett. 2013, 217, 205-216. [CrossRef] [PubMed]

24. Asharani, P.; Hande, M.P.; Valiyaveettil, S. Anti-proliferative activity of silver nanoparticles. BMC Cell Biol. 2009, 10, 65. [CrossRef] [PubMed]

25. Nair, S.; Sasidharan, A.; Rani, V.D.; Menon, D.; Nair, S.; Manzoor, K.; Raina, S. Role of size scale of ZnO nanoparticles and microparticles on toxicity toward bacteria and osteoblast cancer cells. J. Mater. Sci. Mater. Med. 2009, 20, 235-241. [CrossRef] [PubMed]

26. Premanathan, M.; Karthikeyan, K.; Jeyasubramanian, K.; Manivannan, G. Selective toxicity of ZnO nanoparticles toward gram-positive bacteria and cancer cells by apoptosis through lipid peroxidation. Nanomed. Nanotechnol. Biol. Med. 2011, 7, 184-192. [CrossRef] [PubMed]

27. Zou, J.; Li, M.; Zhang, Y.; Zheng, G.; Chen, D.; Chen, S.; Zheng, H. Transport augmentation through the blood-inner ear barriers of guinea pigs treated with 3-nitropropionic acid and patients with acute hearing loss, visualized with 3.0 T MRI. Otol. Neurotol. 2011, 32, 204-212. [CrossRef] [PubMed]

28. Lundqvist, M.; Stigler, J.; Elia, G.; Lynch, I.; Cedervall, T.; Dawson, K.A. Nanoparticle size and surface properties determine the protein corona with possible implications for biological impacts. Proc. Natl. Acad. Sci. USA 2008, 105, 14265-14270. [CrossRef] [PubMed]

29. Jordan, A.; Scholz, R.; Maier-Hauff, K.; van Landeghem, F.K.; Waldoefner, N.; Teichgraeber, U.; Pinkernelle, J.; Bruhn, H.; Neumann, F.; Thiesen, B. The effect of thermotherapy using magnetic nanoparticles on rat malignant glioma. J. Neuro-Oncology 2006, 78, 7-14. [CrossRef] [PubMed]

30. Wang, F.; Gao, F.; Lan, M.; Yuan, H.; Huang, Y.; Liu, J. Oxidative stress contributes to silica nanoparticle-induced cytotoxicity in human embryonic kidney cells. Toxicol. In Vitro 2009, 23, 808-815. [CrossRef] [PubMed]

31. Shang, L.; Nienhaus, K.; Nienhaus, G.U. Engineered nanoparticles interacting with cells: Size matters. J. Nanobiotechnol. 2014, 12, 5. [CrossRef] [PubMed]

32. Zhang, K. Integration of er stress, oxidative stress and the inflammatory response in health and disease. Int. J. Clin. Exp. Med. 2010, 3, 33-40. [PubMed]

33. Ceccon, A.; Tugarinov, V.; Bax, A.; Clore, G.M. Global dynamics and exchange kinetics of a protein on the surface of nanoparticles revealed by relaxation-based solution NMR spectroscopy. J. Am. Chem. Soc. 2016, 138, 5789-5792. [PubMed]

34. Pham, N.; Radajewski, D.; Round, A.; Brennich, M.; Pernot, P.; Biscans, B.; Bonneté, F.; Teychené, S. Coupling high throughput microfluidics and small-angle $\mathrm{X}$-ray scattering to study protein crystallization from solution. Anal. Chem. 2017, 89, 2282-2287. [CrossRef] [PubMed]

35. Pishkar, L.; Taheri, S.; Makarem, S.; Alizadeh Zeinabad, H.; Rahimi, A.; Saboury, A.A.; Falahati, M. Studies on the interaction between nanodiamond and human hemoglobin by surface tension measurement and spectroscopy methods. J. Biomol. Struct. Dyn. 2017, 35, 603-615. [CrossRef] [PubMed]

36. Huang, R.; Lau, B.L. Biomolecule-nanoparticle interactions: Elucidation of the thermodynamics by isothermal titration calorimetry. Biochim. Biophys. Acta Gen. Subj. 2016, 1860, 945-956. [CrossRef] [PubMed]

37. Manyanga, F.; Sithole, A.; Rivera, R.; Karamehmedovic, N.; Martin, N. Use of differential scanning calorimetry (DSC) to study the thermodynamics of DNA-based interactions and nucleic acid-based therapeutics. J. Anal. Pharm. Res. 2016, 2, 00013.

38. Esfandfar, P.; Falahati, M.; Saboury, A. Spectroscopic studies of interaction between cuo nanoparticles and bovine serum albumin. J. Biomol. Struct. Dyn. 2016, 34, 1962-1968. [CrossRef] [PubMed]

39. Jafari Azad, V.; Kasravi, S.; Alizadeh Zeinabad, H.; Memar Bashi Aval, M.; Saboury, A.A.; Rahimi, A.; Falahati, M. Probing the conformational changes and peroxidase-like activity of cytochrome c upon interaction with iron nanoparticles. J. Biomol. Struct. Dyn. 2017, 35, 2565-2577. [CrossRef] [PubMed]

40. Zeinabad, H.A.; Zarrabian, A.; Saboury, A.A.; Alizadeh, A.M.; Falahati, M. Interaction of single and multi wall carbon nanotubes with the biological systems: Tau protein and PC12 cells as targets. Sci. Rep. 2016, 6, 26508. [PubMed] 
41. Zeinabad, H.A.; Kachooei, E.; Saboury, A.A.; Kostova, I.; Attar, F.; Vaezzadeh, M.; Falahati, M. Thermodynamic and conformational changes of protein toward interaction with nanoparticles: A spectroscopic overview. RSC Adv. 2016, 6, 105903-105919. [CrossRef]

42. Hajsalimi, G.; Taheri, S.; Shahi, F.; Attar, F.; Ahmadi, H.; Falahati, M. Interaction of iron nanoparticles with nervous system: An in vitro study. J. Biomol. Struct. Dyn. 2018, 36, 928-937. [CrossRef] [PubMed]

43. Vroman, L.; Adams, A.; Fischer, G.; Munoz, P. Interaction of high molecular weight kininogen, factor XII, and fibrinogen in plasma at interfaces. Blood 1980, 55, 156-159. [PubMed]

44. Walkey, C.D.; Chan, W.C. Understanding and controlling the interaction of nanomaterials with proteins in a physiological environment. Chem. Soc. Rev. 2012, 41, 2780-2799. [CrossRef] [PubMed]

45. Lundqvist, M.; Stigler, J.; Cedervall, T.; Berggård, T.; Flanagan, M.B.; Lynch, I.; Elia, G.; Dawson, K. The evolution of the protein corona around nanoparticles: A test study. ACS Nano 2011, 5, 7503-7509. [CrossRef] [PubMed]

46. Ge, C.; Du, J.; Zhao, L.; Wang, L.; Liu, Y.; Li, D.; Yang, Y.; Zhou, R.; Zhao, Y.; Chai, Z. Binding of blood proteins to carbon nanotubes reduces cytotoxicity. Proc. Natl. Acad. Sci. USA 2011, 108, 16968-16973. [CrossRef] [PubMed]

47. Hu, W.; Peng, C.; Lv, M.; Li, X.; Zhang, Y.; Chen, N.; Fan, C.; Huang, Q. Protein corona-mediated mitigation of cytotoxicity of graphene oxide. ACS Nano 2011, 5, 3693-3700. [CrossRef] [PubMed]

48. Peng, Q.; Zhang, S.; Yang, Q.; Zhang, T.; Wei, X.-Q.; Jiang, L.; Zhang, C.-L.; Chen, Q.-M.; Zhang, Z.-R.; Lin, Y.-F. Preformed albumin corona, a protective coating for nanoparticles based drug delivery system. Biomaterials 2013, 34, 8521-8530. [CrossRef] [PubMed]

49. Wang, L.; Li, J.; Pan, J.; Jiang, X.; Ji, Y.; Li, Y.; Qu, Y.; Zhao, Y.; Wu, X.; Chen, C. Revealing the binding structure of the protein corona on gold nanorods using synchrotron radiation-based techniques: Understanding the reduced damage in cell membranes. J. Am. Chem. Soc. 2013, 135, 17359-17368. [CrossRef] [PubMed]

50. Corbo, C.; Molinaro, R.; Parodi, A.; Furman, N.E.T.; Salvatore, F.; Tasciotti, E. The impact of nanoparticle protein corona on cytotoxicity, immunotoxicity and target drug delivery. Nanomedicine 2016, 11, 81-100. [CrossRef] [PubMed]

51. Treuel, L.; Brandholt, S.; Maffre, P.; Wiegele, S.; Shang, L.; Nienhaus, G.U. Impact of protein modification on the protein corona on nanoparticles and nanoparticle-cell interactions. ACS Nano 2014, 8, 503-513. [CrossRef] [PubMed]

52. Lee, K.J.; Browning, L.M.; Nallathamby, P.D.; Xu, X.-H.N. Study of charge-dependent transport and toxicity of peptide-functionalized silver nanoparticles using zebrafish embryos and single nanoparticle plasmonic spectroscopy. Chem. Res. Toxicol. 2013, 26, 904-917. [CrossRef] [PubMed]

53. Piao, M.J.; Kang, K.A.; Lee, I.K.; Kim, H.S.; Kim, S.; Choi, J.Y.; Choi, J.; Hyun, J.W. Silver nanoparticles induce oxidative cell damage in human liver cells through inhibition of reduced glutathione and induction of mitochondria-involved apoptosis. Toxicol. Lett. 2011, 201, 92-100. [CrossRef] [PubMed]

54. Carlson, C.; Hussain, S.M.; Schrand, A.M.; Braydich-Stolle, L.K.; Hess, K.L.; Jones, R.L.; Schlager, J.J. Unique cellular interaction of silver nanoparticles: Size-dependent generation of reactive oxygen species. J. Phys. Chem. B 2008, 112, 13608-13619. [CrossRef] [PubMed]

55. Sharma, V.K. Aggregation and toxicity of titanium dioxide nanoparticles in aquatic environment-A review. J. Environ. Sci. Health Part A 2009, 44, 1485-1495. [CrossRef] [PubMed]

56. Nel, A.; Xia, T.; Mädler, L.; Li, N. Toxic potential of materials at the nanolevel. Science 2006, 311, 622-627. [CrossRef] [PubMed]

57. Liu, W.; Wu, Y.; Wang, C.; Li, H.C.; Wang, T.; Liao, C.Y.; Cui, L.; Zhou, Q.F.; Yan, B.; Jiang, G.B. Impact of silver nanoparticles on human cells: Effect of particle size. Nanotoxicology 2010, 4, 319-330. [CrossRef] [PubMed]

58. Chithrani, B.D.; Chan, W.C. Elucidating the mechanism of cellular uptake and removal of protein-coated gold nanoparticles of different sizes and shapes. Nano Lett. 2007, 7, 1542-1550. [CrossRef] [PubMed]

59. Kim, T.H.; Kim, M.; Park, H.S.; Shin, U.S.; Gong, M.S.; Kim, H.W. Size-dependent cellular toxicity of silver nanoparticles. J. Biomed. Mater. Res. Part A 2012, 100, 1033-1043. [CrossRef] [PubMed]

60. Favi, P.M.; Gao, M.; Johana Sepúlveda Arango, L.; Ospina, S.P.; Morales, M.; Pavon, J.J.; Webster, T.J. Shape and surface effects on the cytotoxicity of nanoparticles: Gold nanospheres versus gold nanostars. J. Biomed. Mater. Res. Part A 2015, 103, 3449-3462. [CrossRef] [PubMed] 
61. Verma, A.; Stellacci, F. Effect of surface properties on nanoparticle-cell interactions. Small 2010, 6, 12-21. [CrossRef] [PubMed]

62. Champion, J.A.; Mitragotri, S. Role of target geometry in phagocytosis. Proc. Natl. Acad. Sci. USA 2006, 103, 4930-4934. [CrossRef] [PubMed]

63. Li, X.; Gao, H.; Uo, M.; Sato, Y.; Akasaka, T.; Abe, S.; Feng, Q.; Cui, F.; Watari, F. Maturation of osteoblast-like SaoS2 induced by carbon nanotubes. Biomed. Mater. 2008, 4, 015005. [CrossRef] [PubMed]

64. Zhang, Y.; Ali, S.F.; Dervishi, E.; Xu, Y.; Li, Z.; Casciano, D.; Biris, A.S. Cytotoxicity effects of graphene and single-wall carbon nanotubes in neural phaeochromocytoma-derived PC12 cells. ACS Nano 2010, 4, 3181-3186. [CrossRef] [PubMed]

65. Gurr, J.-R.; Wang, A.S.; Chen, C.-H.; Jan, K.-Y. Ultrafine titanium dioxide particles in the absence of photoactivation can induce oxidative damage to human bronchial epithelial cells. Toxicology 2005, 213, 66-73. [CrossRef] [PubMed]

66. Georgieva, J.V.; Kalicharan, D.; Couraud, P.-O.; Romero, I.A.; Weksler, B.; Hoekstra, D.; Zuhorn, I.S. Surface characteristics of nanoparticles determine their intracellular fate in and processing by human blood-brain barrier endothelial cells in vitro. Mol. Ther. 2011, 19, 318-325. [CrossRef] [PubMed]

67. Shahbazi, M.A.; Hamidi, M.; Makila, E.M.; Zhang, H.; Almeida, P.V.; Kaasalainen, M.; Salonen, J.J.; Hirvonen, J.T.; Santos, H.A. The mechanisms of surface chemistry effects of mesoporous silicon nanoparticles on immunotoxicity and biocompatibility. Biomaterials 2013, 34, 7776-7789. [CrossRef] [PubMed]

68. Calatayud, M.P.; Sanz, B.; Raffa, V.; Riggio, C.; Ibarra, M.R.; Goya, G.F. The effect of surface charge of functionalized $\mathrm{Fe}_{3} \mathrm{O}_{4}$ nanoparticles on protein adsorption and cell uptake. Biomaterials 2014, 35, 6389-6399. [CrossRef] [PubMed]

69. Santos, H.A.; Riikonen, J.; Salonen, J.; Mäkilä, E.; Heikkilä, T.; Laaksonen, T.; Peltonen, L.; Lehto, V.-P.; Hirvonen, J. In vitro cytotoxicity of porous silicon microparticles: Effect of the particle concentration, surface chemistry and size. Acta Biomater. 2010, 6, 2721-2731. [CrossRef] [PubMed]

70. Kiss, B.; Bíró, T.; Czifra, G.; Tóth, B.I.; Kertész, Z.; Szikszai, Z.; Kiss, Á.Z.; Juhász, I.; Zouboulis, C.C.; Hunyadi, J. Investigation of micronized titanium dioxide penetration in human skin xenografts and its effect on cellular functions of human skin-derived cells. Exp. Dermatol. 2008, 17, 659-667. [CrossRef] [PubMed]

71. Korani, M.; Rezayat, S.M.; Bidgoli, S.A. Sub-chronic dermal toxicity of silver nanoparticles in guinea pig: Special emphasis to heart, bone and kidney toxicities. Iran. J. Pharm. Res. 2013, 12, 511-519. [PubMed]

72. Narayanan, D.; Geena, M.; Lakshmi, H.; Koyakutty, M.; Nair, S.; Menon, D. Poly-(ethylene glycol) modified gelatin nanoparticles for sustained delivery of the anti-inflammatory drug ibuprofen-sodium: An in vitro and in vivo analysis. Nanomed. Nanotechnol. Biol. Med. 2013, 9, 818-828. [CrossRef] [PubMed]

73. Ema, M.; Matsuda, A.; Kobayashi, N.; Naya, M.; Nakanishi, J. Evaluation of dermal and eye irritation and skin sensitization due to carbon nanotubes. Regul. Toxicol. Pharm. 2011, 61, 276-281. [CrossRef] [PubMed]

74. Kato, S.; Itoh, K.; Yaoi, T.; Tozawa, T.; Yoshikawa, Y.; Yasui, H.; Kanamura, N.; Hoshino, A.; Manabe, N.; Yamamoto, K. Organ distribution of quantum dots after intraperitoneal administration, with special reference to area-specific distribution in the brain. Nanotechnology 2010, 21, 335103. [CrossRef] [PubMed]

75. Zhang, T.; Hu, Y.; Tang, M.; Kong, L.; Ying, J.; Wu, T.; Xue, Y.; Pu, Y. Liver toxicity of cadmium telluride quantum dots (CdTe QDs) due to oxidative stress in vitro and in vivo. Int. J. Mol. Sci. 2015, 16, 23279-23299. [CrossRef] [PubMed]

76. Trickler, W.J.; Lantz, S.M.; Murdock, R.C.; Schrand, A.M.; Robinson, B.L.; Newport, G.D.; Schlager, J.J.; Oldenburg, S.J.; Paule, M.G.; Slikker, W., Jr. Silver nanoparticle induced blood-brain barrier inflammation and increased permeability in primary rat brain microvessel endothelial cells. Toxicol. Sci. 2010, 118, 160-170. [CrossRef] [PubMed]

77. Truong, L.; Saili, K.S.; Miller, J.M.; Hutchison, J.E.; Tanguay, R.L. Persistent adult zebrafish behavioral deficits results from acute embryonic exposure to gold nanoparticles. Comp. Biochem. Physiol. C Toxicol. Pharmacol. 2012, 155, 269-274. [CrossRef] [PubMed]

78. Sharma, H.S. Hyperthermia induced brain oedema: Current status and future perspectives. Indian J. Med. Res. 2006, 123, 629-652.

79. Hardman, R. A toxicologic review of quantum dots: Toxicity depends on physicochemical and environmental factors. Environ. Health Perspect. 2006, 114, 165-172. [CrossRef] [PubMed] 
80. Muldoon, L.L.; Sàndor, M.; Pinkston, K.E.; Neuwelt, E.A. Imaging, distribution, and toxicity of superparamagnetic iron oxide magnetic resonance nanoparticles in the rat brain and intracerebral tumor. Neurosurgery 2005, 57, 785-796. [CrossRef] [PubMed]

81. Pongrac, I.M.; Pavičić, I.; Milić, M.; Ahmed, L.B.; Babič, M.; Horák, D.; Vrček, I.V.; Gajović, S. Oxidative stress response in neural stem cells exposed to different superparamagnetic iron oxide nanoparticles. Int. J. Nanomed. 2016, 11, 1701-1715.

82. Jeng, H.A.; Swanson, J. Toxicity of metal oxide nanoparticles in mammalian cells. J. Environ. Sci. Health Part A 2006, 41, 2699-2711. [CrossRef] [PubMed]

83. Dal Bosco, L.; Weber, G.E.; Parfitt, G.M.; Paese, K.; Gonçalves, C.O.; Serodre, T.M.; Furtado, C.A.; Santos, A.P.; Monserrat, J.M.; Barros, D.M. Pegylated carbon nanotubes impair retrieval of contextual fear memory and alter oxidative stress parameters in the rat hippocampus. Biomed. Res. Int. 2015, 2015, 104135. [CrossRef] [PubMed]

84. Wang, J.; Sun, P.; Bao, Y.; Liu, J.; An, L. Cytotoxicity of single-walled carbon nanotubes on PC12 cells. Toxicol. In Vitro 2011, 25, 242-250. [CrossRef] [PubMed]

85. Mahto, S.K.; Yoon, T.H.; Rhee, S.W. Cytotoxic effects of surface-modified quantum dots on neuron-like pc12 cells cultured inside microfluidic devices. Biochip J. 2010, 4, 82-88. [CrossRef]

86. Sung, J.H.; Ji, J.H.; Yoon, J.U.; Kim, D.S.; Song, M.Y.; Jeong, J.; Han, B.S.; Han, J.H.; Chung, Y.H.; Kim, J. Lung function changes in sprague-dawley rats after prolonged inhalation exposure to silver nanoparticles. Inhal. Toxicol. 2008, 20, 567-574. [CrossRef] [PubMed]

87. Lanone, S.; Rogerieux, F.; Geys, J.; Dupont, A.; Maillot-Marechal, E.; Boczkowski, J.; Lacroix, G.; Hoet, P. Comparative toxicity of 24 manufactured nanoparticles in human alveolar epithelial and macrophage cell lines. Part. Fibre Toxicol. 2009, 6, 14. [CrossRef] [PubMed]

88. Ahamed, M.; Siddiqui, M.A.; Akhtar, M.J.; Ahmad, I.; Pant, A.B.; Alhadlaq, H.A. Genotoxic potential of copper oxide nanoparticles in human lung epithelial cells. Biochem. Biophys. Res. Commun. 2010, 396, 578-583. [CrossRef] [PubMed]

89. Brunner, T.J.; Wick, P.; Manser, P.; Spohn, P.; Grass, R.N.; Limbach, L.K.; Bruinink, A.; Stark, W.J. In vitro cytotoxicity of oxide nanoparticles: Comparison to asbestos, silica, and the effect of particle solubility. Environ. Sci. Technol. 2006, 40, 4374-4381. [CrossRef] [PubMed]

90. Könczöl, M.; Ebeling, S.; Goldenberg, E.; Treude, F.; Gminski, R.; Gieré, R.; Grobéty, B.; Rothen-Rutishauser, B.; Merfort, I.; Mersch-Sundermann, V. Cytotoxicity and genotoxicity of size-fractionated iron oxide (magnetite) in A549 human lung epithelial cells: Role of ROS, JNK, and NF-кB. Chem. Res. Toxicol. 2011, 24, 1460-1475. [CrossRef] [PubMed]

91. Guan, R.; Kang, T.; Lu, F.; Zhang, Z.; Shen, H.; Liu, M. Cytotoxicity, oxidative stress, and genotoxicity in human hepatocyte and embryonic kidney cells exposed to zno nanoparticles. Nanoscale Res. Lett. 2012, 7, 602. [CrossRef] [PubMed]

92. Davoren, M.; Herzog, E.; Casey, A.; Cottineau, B.; Chambers, G.; Byrne, H.J.; Lyng, F.M. In vitro toxicity evaluation of single walled carbon nanotubes on human A549 lung cells. Toxicol. In Vitro 2007, 21, 438-448. [CrossRef] [PubMed]

93. Huang, G.G.; Wang, C.-T.; Tang, H.-T.; Huang, Y.-S.; Yang, J. Zno nanoparticle-modified infrared internal reflection elements for selective detection of volatile organic compounds. Anal. Chem. 2006, 78, 2397-2404. [CrossRef] [PubMed]

94. Choi, Y.J.; Kim, Y.J.; Lee, J.W.; Lee, Y.; Lim, Y.-B.; Chung, H.W. Cyto-/genotoxic effect of CdSe/ZnS quantum dots in human lung adenocarcinoma cells for potential photodynamic UV therapy applications. J. Nanosci. Nanotechnol. 2012, 12, 2160-2168. [CrossRef] [PubMed]

95. Taju, G.; Majeed, S.A.; Nambi, K.; Hameed, A.S. In vitro assay for the toxicity of silver nanoparticles using heart and gill cell lines of catla catla and gill cell line of labeo rohita. Comp. Biochem. Physiol. C: Toxicol. Pharmacol. 2014, 161, 41-52. [CrossRef] [PubMed]

96. Baratli, Y.; Charles, A.-L.; Wolff, V.; Tahar, L.B.; Smiri, L.; Bouitbir, J.; Zoll, J.; Piquard, F.; Tebourbi, O.; Sakly, M. Impact of iron oxide nanoparticles on brain, heart, lung, liver and kidneys mitochondrial respiratory chain complexes activities and coupling. Toxic. In Vitro 2013, 27, 2142-2148. [CrossRef] [PubMed]

97. Hosseinpour, M.; Azimirad, V.; Alimohammadi, M.; Shahabi, P.; Sadighi, M.; Nejad, G.G. The cardiac effects of carbon nanotubes in rat. BioImpacts BI 2016, 6, 79-84. [CrossRef] [PubMed] 
98. Harvey, J.; Dong, L.; Kim, K.; Hayden, J.; Wang, J. Uptake of single-walled carbon nanotubes conjugated with DNA by microvascular endothelial cells. J. Nanotechnol. 2011, 2012, 196189. [CrossRef]

99. Nguyen, K.C.; Rippstein, P.; Tayabali, A.F.; Willmore, W.G. Mitochondrial toxicity of cadmium telluride quantum dot nanoparticles in mammalian hepatocytes. Toxicol. Sci. 2015, 146, 31-42. [CrossRef] [PubMed]

100. Trop, M.; Novak, M.; Rodl, S.; Hellbom, B.; Kroell, W.; Goessler, W. Silver-coated dressing acticoat caused raised liver enzymes and argyria-like symptoms in burn patient. J. Trauma Acute Care Surg. 2006, 60, 648-652. [CrossRef] [PubMed]

101. Mavon, A.; Miquel, C.; Lejeune, O.; Payre, B.; Moretto, P. In vitro percutaneous absorption and in vivo stratum corneum distribution of an organic and a mineral sunscreen. Skin Sharm. Physiol. 2007, 20, 10-20. [CrossRef] [PubMed]

102. Alili, L.; Chapiro, S.; Marten, G.U.; Schmidt, A.M.; Zanger, K.; Brenneisen, P. Effect of $\mathrm{Fe}_{3} \mathrm{O}_{4}$ nanoparticles on skin tumor cells and dermal fibroblasts. BioMed Res. Int. 2015, 2015, 530957.

103. Zhang, L.W.; Zeng, L.; Barron, A.R.; Monteiro-Riviere, N.A. Biological interactions of functionalized single-wall carbon nanotubes in human epidermal keratinocytes. Int. J. Toxicol. 2007, 26, 103-113. [CrossRef] [PubMed]

104. Patlolla, A.; Knighten, B.; Tchounwou, P. Multi-walled carbon nanotubes induce cytotoxicity, genotoxicity and apoptosis in normal human dermal fibroblast cells. Ethn. Dis. 2010, 20, 65-72.

105. Ryman-Rasmussen, J.P.; Riviere, J.E.; Monteiro-Riviere, N.A. Penetration of intact skin by quantum dots with diverse physicochemical properties. Toxicol. Sci. 2006, 91, 159-165. [CrossRef] [PubMed]

106. Samberg, M.E.; Oldenburg, S.J.; Monteiro-Riviere, N.A. Evaluation of silver nanoparticle toxicity in skin in vivo and keratinocytes in vitro. Environ. Health Perspect. 2010, 118, 407-413. [CrossRef] [PubMed]

107. Arora, S.; Jain, J.; Rajwade, J.; Paknikar, K. Interactions of silver nanoparticles with primary mouse fibroblasts and liver cells. Toxicol. Appl. Pharm. 2009, 236, 310-318. [CrossRef] [PubMed]

108. Derfus, A.M.; Chan, W.C.; Bhatia, S.N. Probing the cytotoxicity of semiconductor quantum dots. Nano Lett. 2004, 4, 11-18. [CrossRef] [PubMed]

109. Murali, M.; Suganthi, P.; Athif, P.; Bukhari, A.S.; Mohamed, H.S.; Basu, H.; Singhal, R. Histological alterations in the hepatic tissues of $\mathrm{Al}_{2} \mathrm{O}_{3}$ nanoparticles exposed freshwater fish oreochromis mossambicus. J. Trace Elem. Med. Biol. 2017, 44, 125-131. [CrossRef] [PubMed]

110. Liu, H.; Ma, L.; Liu, J.; Zhao, J.; Yan, J.; Hong, F. Toxicity of nano-anatase $\mathrm{TiO}_{2}$ to mice: Liver injury, oxidative stress. Toxic. Environ. Chem. 2010, 92, 175-186. [CrossRef]

111. Buford, M.C.; Hamilton, R.F.; Holian, A. A comparison of dispersing media for various engineered carbon nanoparticles. Part. Fibre Toxicol. 2007, 4, 6. [CrossRef] [PubMed]

112. Kermanizadeh, A.; Gaiser, B.K.; Hutchison, G.R.; Stone, V. An in vitro liver model-assessing oxidative stress and genotoxicity following exposure of hepatocytes to a panel of engineered nanomaterials. Part. Fibre Toxicol. 2012, 9, 28. [CrossRef] [PubMed]

113. Lin, P.; Chen, J.-W.; Chang, L.W.; Wu, J.-P.; Redding, L.; Chang, H.; Yeh, T.-K.; Yang, C.S.; Tsai, M.-H.; Wang, H.-J. Computational and ultrastructural toxicology of a nanoparticle, quantum dot 705, in mice. Environ. Sci. Technol. 2008, 42, 6264-6270. [CrossRef] [PubMed]

114. Zhang, X.-D.; Wu, D.; Shen, X.; Liu, P.-X.; Fan, F.-Y.; Fan, S.-J. In vivo renal clearance, biodistribution, toxicity of gold nanoclusters. Biomaterials 2012, 33, 4628-4638. [CrossRef] [PubMed]

115. Khlebtsov, N.; Dykman, L. Biodistribution and toxicity of engineered gold nanoparticles: A review of in vitro and in vivo studies. Chem. Soc. Rev. 2011, 40,1647-1671. [CrossRef] [PubMed]

116. Yan, G.; Huang, Y.; Bu, Q.; Lv, L.; Deng, P.; Zhou, J.; Wang, Y.; Yang, Y.; Liu, Q.; Cen, X. Zinc oxide nanoparticles cause nephrotoxicity and kidney metabolism alterations in rats. J. Environ. Sci. Health Part A 2012, 47, 577-588. [CrossRef] [PubMed]

117. Privalova, L.I.; Katsnelson, B.A.; Loginova, N.V.; Gurvich, V.B.; Shur, V.Y.; Valamina, I.E.; Makeyev, O.H.; Sutunkova, M.P.; Minigalieva, I.A.; Kireyeva, E.P. Subchronic toxicity of copper oxide nanoparticles and its attenuation with the help of a combination of bioprotectors. Int. J. Mol. Sci. 2014, 15, 12379-12406. [CrossRef] [PubMed]

118. Lewinski, N.; Colvin, V.; Drezek, R. Cytotoxicity of nanoparticles. Small 2008, 4, 26-49. [CrossRef] [PubMed]

119. Demir, E.; Burgucu, D.; Turna, F.; Aksakal, S.; Kaya, B. Determination of $\mathrm{TiO}_{2}, \mathrm{ZrO}_{2}$, and $\mathrm{Al}_{2} \mathrm{O}_{3}$ nanoparticles on genotoxic responses in human peripheral blood lymphocytes and cultured embyronic kidney cells. J. Toxic. Environ. Health Part A 2013, 76, 990-1002. [CrossRef] [PubMed] 
120. Shang, S.; Yang, S.-Y.; Liu, Z.-M.; Yang, X. Oxidative damage in the kidney and brain of mice induced by different nano-materials. Front. Biol. 2015, 10, 91-96. [CrossRef]

121. Reddy, A.R.N.; Krishna, D.; Himabindu, V.; Reddy, Y.N. Single walled carbon nanotubes induce cytotoxicity and oxidative stress in hek293 cells. Toxicol. Environ. Chem. 2014, 96, 931-940. [CrossRef]

122. Mao, W.-P.; Ye, J.-L.; Guan, Z.-B.; Zhao, J.-M.; Zhang, C.; Zhang, N.-N.; Jiang, P.; Tian, T. Cadmium induces apoptosis in human embryonic kidney (HEK) 293 cells by caspase-dependent and-independent pathways acting on mitochondria. Toxicol. In Vitro 2007, 21, 343-354. [CrossRef] [PubMed]

123. Sardari, R.R.R.; Zarchi, S.R.; Talebi, A.; Nasri, S.; Imani, S.; Khoradmehr, A.; Sheshde, S.A.R. Toxicological effects of silver nanoparticles in rats. Afr. J. Microbiol. Res. 2012, 6, 5587-5593.

124. Krug, L.T.; Moser, J.M.; Dickerson, S.M.; Speck, S.H. Inhibition of NF-кB activation in vivo impairs establishment of gammaherpesvirus latency. PLoS Pathog. 2007, 3, e11. [CrossRef] [PubMed]

125. Ates, M.; Demir, V.; Arslan, Z.; Kaya, H.; Yılmaz, S.; Camas, M. Chronic exposure of tilapia (oreochromis niloticus) to iron oxide nanoparticles: Effects of particle morphology on accumulation, elimination, hematology and immune responses. Aquat. Toxicol. 2016, 177, 22-32. [CrossRef] [PubMed]

126. Clichici, S.; Biris, A.R.; Catoi, C.; Filip, A.; Tabaran, F. Short-term splenic impact of single-strand DNA functionalized multi-walled carbon nanotubes intraperitoneally injected in rats. J. Appl. Toxicol. JAT 2014, 34, 332-344. [CrossRef] [PubMed]

127. Gagné, F.; Auclair, J.; Turcotte, P.; Fournier, M.; Gagnon, C.; Sauvé, S.; Blaise, C. Ecotoxicity of cdte quantum dots to freshwater mussels: Impacts on immune system, oxidative stress and genotoxicity. Aquat. Toxicol. 2008, 86, 333-340. [CrossRef] [PubMed]

128. Wang, T.; Hsieh, H.; Hsieh, Y.; Chiang, C.; Sun, Y.; Wang, C. The in vivo biodistribution and fate of cdse quantum dots in the murine model: A laser ablation inductively coupled plasma mass spectrometry study. Anal. Bioanal. Chem. 2012, 404, 3025-3036. [CrossRef] [PubMed]

129. Chen, L.-D.; Liu, J.; Yu, X.-F.; He, M.; Pei, X.-F.; Tang, Z.-Y.; Wang, Q.-Q.; Pang, D.-W.; Li, Y. The biocompatibility of quantum dot probes used for the targeted imaging of hepatocellular carcinoma metastasis. Biomaterials 2008, 29, 4170-4176. [CrossRef] [PubMed]

130. Loeschner, K.; Hadrup, N.; Qvortrup, K.; Larsen, A.; Gao, X.; Vogel, U.; Mortensen, A.; Lam, H.R.; Larsen, E.H. Distribution of silver in rats following 28 days of repeated oral exposure to silver nanoparticles or silver acetate. Part. Fibre Toxicol. 2011, 8, 18. [CrossRef] [PubMed]

131. Singh, M.; Harris-Birtill, D.C.; Markar, S.R.; Hanna, G.B.; Elson, D.S. Application of gold nanoparticles for gastrointestinal cancer theranostics: A systematic review. Nanomed. Nanotechnol. Biol. Med. 2015, 11, 2083-2098. [CrossRef] [PubMed]

132. Wang, Z.M.; Kunets, V.P.; Xie, Y.Z.; Schmidbauer, M.; Dorogan, V.G.; Mazur, Y.I.; Salamo, G.J. Multilayer self-organization of ingaas quantum wires on GaAs surfaces. Phys. Lett. A 2010, 375, 170-173. [CrossRef]

133. Takenaka, S.; Karg, E.; Roth, C.; Schulz, H.; Ziesenis, A.; Heinzmann, U.; Schramel, P.; Heyder, J. Pulmonary and systemic distribution of inhaled ultrafine silver particles in rats. Environ. Health Perspect. 2001, 109, 547-551. [CrossRef] [PubMed]

134. Pasupuleti, S.; Alapati, S.; Ganapathy, S.; Anumolu, G.; Pully, N.R.; Prakhya, B.M. Toxicity of zinc oxide nanoparticles through oral route. Toxicol. Ind. Health 2012, 28, 675-686. [CrossRef] [PubMed]

135. Upadhyayula, V.K.; Deng, S.; Mitchell, M.C.; Smith, G.B. Application of carbon nanotube technology for removal of contaminants in drinking water: A review. Sci. Total Environ. 2009, 408, 1-13. [CrossRef] [PubMed]

136. Poland, C.A.; Duffin, R.; Kinloch, I.; Maynard, A.; Wallace, W.A.; Seaton, A.; Stone, V.; Brown, S.; MacNee, W.; Donaldson, K. Carbon nanotubes introduced into the abdominal cavity of mice show asbestos-like pathogenicity in a pilot study. Nature Nanotechnol. 2008, 3, 423-428. [CrossRef] [PubMed]

137. Simkó, M.; Nentwich, M.; Gazsó, A.; Fiedeler, U. How Nanoparticles Enter the Human Body and Their Effects There; Nanotrust Dossier No. 003en; Institute of Technology Assessment of the Austrian Academy of Sciences: Vienna, Austria, 2010.

138. Savolainen, K.; Alenius, H.; Norppa, H.; Pylkkänen, L.; Tuomi, T.; Kasper, G. Risk assessment of engineered nanomaterials and nanotechnologies-A review. Toxicology 2010, 269, 92-104. [CrossRef] [PubMed]

139. Wang, L.; Nagesha, D.K.; Selvarasah, S.; Dokmeci, M.R.; Carrier, R.L. Toxicity of cdse nanoparticles in Caco-2 cell cultures. J. Nanobiotechnol. 2008, 6, 11. [CrossRef] [PubMed] 
140. Stensberg, M.C.; Wei, Q.; McLamore, E.S.; Porterfield, D.M.; Wei, A.; Sepúlveda, M.S. Toxicological studies on silver nanoparticles: Challenges and opportunities in assessment, monitoring and imaging. Nanomedicine 2011, 6, 879-898. [CrossRef] [PubMed]

141. He, Y.; Du, Z.; Ma, S.; Liu, Y.; Li, D.; Huang, H.; Jiang, S.; Cheng, S.; Wu, W.; Zhang, K. Effects of green-synthesized silver nanoparticles on lung cancer cells in vitro and grown as xenograft tumors in vivo. Int. J. Nanomed. 2016, 11, 1879-1887. [CrossRef] [PubMed]

142. Selim, M.E.; Abd-Elhakim, Y.M.; Al-Ayadhi, L.Y. Pancreatic response to gold nanoparticles includes decrease of oxidative stress and inflammation in autistic diabetic model. Cell. Phys. Biochem. 2015, 35, 586-600. [CrossRef] [PubMed]

143. Pašukonienè, V.; Mlynska, A.; Steponkienè, S.; Poderys, V.; Matulionytė, M.; Karabanovas, V.; Statkutè, U.; Purvinienè, R.; Kraśko, J.A.; Jagminas, A. Accumulation and biological effects of cobalt ferrite nanoparticles in human pancreatic and ovarian cancer cells. Medicina 2014, 50, 237-244. [CrossRef] [PubMed]

144. Park, H.-S.; Kim, S.-J.; Lee, T.-J.; Kim, G.-Y.; Meang, E.; Hong, J.-S.; Kim, S.-H.; Koh, S.-B.; Hong, S.-G.; Sun, Y.-S. A 90-day study of sub-chronic oral toxicity of $20 \mathrm{~nm}$ positively charged zinc oxide nanoparticles in Sprague Dawley rats. Int. J. Nanomed. 2014, 9, 93-107.

145. Nakayama, M.; Sasaki, R.; Ogino, C.; Tanaka, T.; Morita, K.; Umetsu, M.; Ohara, S.; Tan, Z.; Nishimura, Y.; Akasaka, H. Titanium peroxide nanoparticles enhanced cytotoxic effects of X-ray irradiation against pancreatic cancer model through reactive oxygen species generation in vitro and in vivo. Radiat. Oncol. 2016, 11, 91. [CrossRef] [PubMed]

146. Mocan, T.; Matea, C.T.; Cojocaru, I.; Ilie, I.; Tabaran, F.A.; Zaharie, F.; Iancu, C.; Bartos, D.; Mocan, L. Photothermal treatment of human pancreatic cancer using pegylated multi-walled carbon nanotubes induces apoptosis by triggering mitochondrial membrane depolarization mechanism. J. Cancer 2014, 5, 679-688. [CrossRef] [PubMed]

147. Chang, S.-Q.; Dai, Y.-D.; Kang, B.; Han, W.; Mao, L.; Chen, D. Uv-enhanced cytotoxicity of thiol-capped cdte quantum dots in human pancreatic carcinoma cells. Toxicol. Lett. 2009, 188, 104-111. [CrossRef] [PubMed]

148. Zou, J.; Feng, H.; Mannerström, M.; Heinonen, T.; Pyykkö, I. Toxicity of silver nanoparticle in rat ear and BALB/c 3 T3 cell line. J. Nanobiotechnol. 2014, 12, 52. [CrossRef] [PubMed]

149. Kong, S.D.; Lee, J.; Ramachandran, S.; Eliceiri, B.P.; Shubayev, V.I.; Lal, R.; Jin, S. Magnetic targeting of nanoparticles across the intact blood-brain barrier. J. Control. Release 2012, 164, 49-57. [CrossRef] [PubMed]

150. Thompson, J.; Hipwell, E.; Loo, H.V.; Bannigan, J. Effects of cadmium on cell death and cell proliferation in chick embryos. Reprod. Toxic. 2005, 20, 539-548. [CrossRef] [PubMed]

151. Gerber, A.; Bundschuh, M.; Klingelhofer, D.; Groneberg, D.A. Gold nanoparticles: Recent aspects for human toxicology. J. Occup. Med. Toxicol. 2013, 8, 32. [CrossRef] [PubMed]

152. Park, J.-H.; Jeong, H.; Hong, J.; Chang, M.; Kim, M.; Chuck, R.S.; Lee, J.K.; Park, C.-Y. The effect of silica nanoparticles on human corneal epithelial cells. Sci. Rep. 2016, 6, 37762. [CrossRef] [PubMed]

153. Olson, J.L.; Velez-Montoya, R.; Mandava, N.; Stoldt, C.R. Intravitreal silicon-based quantum dots as neuroprotective factors in a model of retinal photoreceptor degenerationsilicon quantum dots as neuroprotective factors. Investig. Ophthalmol. Vis. Sci. 2012, 53, 5713-5721. [CrossRef] [PubMed]

(C) 2018 by the authors. Licensee MDPI, Basel, Switzerland. This article is an open access article distributed under the terms and conditions of the Creative Commons Attribution (CC BY) license (http:// creativecommons.org/licenses/by/4.0/). 